\title{
Seçme Hakkının Yaş Bakımından Sınırlanması ve Osmanlı-Türkiye Anayasacılığındaki Evrimi
}

\author{
(Restriction of the Right to Vote in Terms of Age and Its Evolution in \\ Ottoman-Turkey Constitutionalism)
}

Abdullah Sezer* (iD)

\begin{abstract}
"If you're old enough to fight, you're old enough to vote"1.

- Resul Tosun (Ak Parti): "Seçme yaşı 18, seçilme yaşı 30; aslında, ortada bir çelişki var. ... Biz, Türkiye’yi yönetecek insanları seçebilmek için 18 yaşını yeterli görürken, ... eğer meseleye sadece yaş açısından bakarsak, bir çelişki içinde olduğumuzu görürüz".

- Orhan Eraslan (CHP): "Zekâ yaşına da bakmak lazım!"
\end{abstract}

[TBMM Genel Kurulu, 01.04.2003²].

\section{öz}

Seçme hakkı, birey ve devlet arasında köprü kuran siyasal haklar kategorisinde yer alır. Bu hak, devletin oluşumu ve karar alma sürecine bireyin katılımını sağladığı için, demokrasinin zorunlu unsurlarındandır.

Önceleri yalnızca erkeklerin belli bir kısmına ait olan seçme hakkı, zamanla eşitliğe uygun biçimde herkese tanınmıştır. Böylece, evrensel ilkelerden bir olan genel oy ilkesine ulaşılmıştır. Ancak genel oy ilkesi, makul sınırlar koymayı engellemez. Diğer bir deyişle genel oy, her insanın seçme hakkını kullanması anlamına gelmez. Söz konusu makûl sınırlardan biri de, yaş şartıdır.

Seçme hakkı, Anayasa'da 67. maddede düzenlenir. İnsan Hakları Avrupa Sözleşmesi’nde (İHAS) düzenlenmeyen serbest seçim hakkı ise, İnsan Hakları Avrupa Sözleşmesi’ne Ek 1 no.lu Protokol m. 3’le düzenlenmiştir.

Bu bağlamda, ülkemizde seçmen yaşı - 1934’te 18 yaştan 22 yaşa yükseltme hariç - sürekli düşme eğilimi göstererek, 1995 Anayasa değişikliği ile 18 yaşa düşürülmüştür. Seçilme yaşı ise, 2017 Anayasa değişikliği ile 18 yaşa düşürülmüştür. Böylece, seçme ve seçilme yaşı eşitlenmiştir.

Oy hakkında temel ilke eşitliktir. Eşitlik bağlamında, yaş, seçim türü, vb. açılardan ideal ilkeler belirlenebilir.

Anahtar Kelimeler: Seçim, Seçmen yaşı, Serbest seçim hakkı, Genel oy, Siyasî haklar, vs.

* Doç. Dr., Marmara Üniversitesi Hukuk Fakültesi Anayasa Hukuku Anabilim Dalı Öğretim Üyesi, abdullah.sezer@ marmara.edu.tr, ORCID: 0000-0001-6633-938X.

1 Bob Brown, 'If You're Old Enough to Fight, You're Old Enough to Vote' (2020) 43/30, August, Public Land \& Resources Law Review 62. https://scholarship.law.umt.edu/plrlr/vol43/iss1/30 (erişim tarihi: 11.03.2021).

2 TBMM Tutanak Dergisi, Dönem: 22, Yasama Yılı: 1, Birleşim 59, T. 01.04.2003, s. 63.

Sorumlu Yazar/Correspondence Author: Abdullah Sezer

E-posta/E-mail: abdullah.sezer@marmara.edu.tr

Geliş Tarihi/Received: $\quad$ 15.09.2021

Kabul Tarihi/Accepted: 


\section{ABSTRACT}

The category of political rights builds the bridge between the individual and the state. The rights to vote and be elected are among the rights in this category. These rights are essential elements of democracy, as they contribute to the formation of the state and the participation of the individual in the decisionmaking process.

The right to vote, which previously belonged only to a certain part of men, has been granted to everyone in accordance with equality over time. Thus, the principle of universal suffrage, which is one of the universal principles, has been reached. However, the principle of universal suffrage does not preclude setting reasonable limits. In other words, universal suffrage does not mean that every person can exercise their right to vote. One of these reasonable limits is the age requirement.

The right to free elections is regulated in Article 67 of the Constitution. The right to free elections, which is not regulated in the European Convention for the Protection of Human Rights and Fundamental Freedoms (ECHR), is regulated by article 3 of First Protocol to the Convention for the Protection of Human Rights and Fundamental Freedoms.

In this context, the voting age in our country has generally tended to decrease. However, in 1934 rise from 18 to 22 is excluded. The voting age was reduced to 18 with the 1995 constitutional amendment. The election age was reduced to 18 with the 2017 Constitutional Amendment. Thus, voting and election age are equalized.

The basic principle about voting is equality. In the context of equality, age, type of election, etc. some ideal principles can be determined.

Keywords: Election, Voting age, Right to free election, Universal suffrage, Political rights, etc.

\section{GIRIŞ: ÖN SAPTAMALAR}

Antik dönemde, kadınlar doğrudan demokraside karar alma süreçlerine katılamadığı gibi, erkekler dahi örneğin üretici ise, her yıl yeniden belirlenen miktarda mahsûl üretemediği takdirde bu olanaktan yoksun kilınabiliyordu.

Demokrasi tarihi, antik dönemde yalnızca erkeklerin karara katıldığı ilkel modelden günümüze, uzun bir evrimi yansıtır. Sonraları oy hakkı genişlese ve seçmen yaşı kademeli biçimde düşse de, sürece vekillerin girişi ve siyasal partilerin doğuşu ile, oyun değeri görece azaldı. Artık modern Dünyada seçmen, parlamento-parti-aday üçgeninde süzgeçten geçirilerek sunulan seçeneklerden birini tercih etmek zorunda... ${ }^{3}$

"Seçmen yaşının on sekiz olmasını isteyen radikal görüşler hukukî, ekonomik, psikolojik ve sosyo-politik diyebileceğimiz birtakım nedenlerden hareket ederek, hem yukardaki gelenekçi görüşlere cevap vermişler ve hem de yeni bazı gerekçeler ileri sürmüşlerdir"4.

Prof. Karamustafaoğlu, 1970’te yayınlanan eserinde işte böyle yazıyor, 18 yaşı destekliyordu. Bugün ise, seçme yaşı bile 18'e düştü...

3 Abdullah Sezer, Demokrasi Teorisi ve Pratiğinde Seçim Barajları [Adalet-İstikrar İkileminde \% 10 Ulusal Baraj Açısından Karşılaştırmalı Bir Analiz] (Legal 2014) 5.

4 Tunçer Karamustafaoğlu, Seçme Hakkının Demokratik İlkeleri (Ankara Üniversitesi Hukuk Fakültesi 1970) 175. 
Günümüzde ülkemizden birkaçyaş şartı: Bisiklet kullanmak için 11; motorsuz taşıt için 13; vasiyet yapabilmek için 15, evlenmek için 17; memur, seçmen, milletvekili, bakan, sendika, dernek veya parti kurucusu olmak, marketten sigara satın alabilmek için 18; asker olmak için 19; büyük otobüs kullanmak için 24; evlât edinmek için 30; Cumhurbaşkanı olmak için 40; Anayasa Mahkemesi (AYM) üyesi olmak için 45 yaş doldurulmalı...

\section{A. SEÇME HAKKI AÇISINDAN ÖN SAPTAMALAR}

Öncelikle, seçme hakkı ve yaş şartı açısından birtakım ön saptamalar belirlenecektir.

\section{Seçme hakkı, siyasal haklardan biridir}

Seçme hakkı, anayasalarda siyasal haklar kategorisinde düzenlenir. Siyasal haklar ise, klâsik tasnifte aktif statü hakları (isteme hakları), gelişmeci tasnifte ise I. kuşak haklar listesinde yer alır.

Nitekim 1982 Anayasası’nda, "seçme, seçilme ve siyasî faaliyette bulunma hakları" kenar başlıklı m. 67, "siyasî haklar ve ödevler" bölümündedir.

\section{Seçme hakkı, oy hakkının aktif boyutunu oluşturur}

İnsan Hakları Avrupa Mahkemesi’ne (İHAM) göre, serbest seçim hakkı iki boyutludur (aktifpasif seçim hakk1 ${ }^{5}$ ): Oy verme ve seçme hakkı "aktif” boyutunu, aday olma ve seçilme hakkı ise "pasif” boyutunu oluşturur ${ }^{6}$. Kullanılan bu dil, seçmen sıfatıyla seçime aktif biçimde katılma hakkı ile seçimde kendini sadece pasif biçimde aday gösterme ve seçildiği takdirde vekil olma hakları arasındaki ayrımı yansıtır?

Mahkeme’nin taraf devletlere tanıdığı takdir marjı, aktif boyutta daha dardır. İHAM, seçme hakkına yönelen sınırlamaları katı ölçülülük testine tâbi tutmak suretiyle, daha sıkı koruma sağlar ${ }^{8}$. Daha açık deyişle, seçme hakkı, seçilme hakkına nazaran daha güçlü bir korumaya sahiptir ${ }^{9}$.

5 Aktif-pasif oy hakkı ayrımı, aktif-pasif yurttaş ayrımından farklıdır: Aktif-pasif oy hakkında, iki tarafın kullandığı ve birbirini tamamlayan iki hak (seçme ve seçilme) vardır. Oysa aktif-pasif yurttaş ayrımı, özellikle hakkın aktif tarafı (seçmen) olmanın belli miktar varlık/mülkiyete sahip olma veya vergi ödeme şartına bağlanmasıdır. Kökeni Eski Yunan’a dek uzayan ayrımın etkisi modern hukukta hâlâ devam etmektedir. Örn. mevzuatımızda dernek üyesi olup aidat ödemeyen pasif üyedir. Adı geçer, ancak oy kullanamaz.

6 Hakkın 2 grup güvencesinden söz edilir: Aktif ve pasif seçim hakkı, hakkın sübjektif (öznesel) güvenceleridir. Objektif (kurumsal) güvenceler ise seçim ilkeleridir. Tolga Şirin, 'İnsan Hakları Avrupa Sözleşmesi’ne Göre Serbest Seçim Hakkı' (2011) 17/1-2 Marmara Üniversitesi Hukuk Fakültesi Hukuk Araştırmaları Dergisi 314 vd.

7 David J. Harris \& Michael Q’Boyle \& Ed P. Bates \& Colin Warbrick, Avrupa İnsan Hakları Sözleşmesi Hukuku Çev. Mehveş Bingöllü Kılıcı \& Ulaş Karan (Avrupa Konseyi 2009) 739.

8 İHAM, Ždanoka v. Latvia, Grand Chamber, App. No. 58278/00, Judg. 16.06.2006, §115(e).

9 Osman Doğru \& Atilla Nalbant, İnsan Hakları Avrupa Sözleșmesi: Açıklama ve Önemli Kararlar C. 2 (Avrupa Konseyi 2013) 818. 
$\mathrm{Bu}$ bağlamda, seçme ve seçilme hakkına yönelik sınırlamalar da farklılaşmaktadır. Seçmenlerin geleneksel olarak taşıması gereken başlıca 3 kategori koşul bağlamında somutlaşan sınırlar, İHAS’a Ek Protokol $1 \mathrm{~m}$. 3'le bağdaşabilir niteliktedir: Yaş, ikamet, vatandaşl1k ${ }^{10}$.

\section{Seçme hakkı, devlete pozitif yükümlülük de getirir}

İnsan Hakları Avrupa Sözleşmesi’ne Ek 1 No.lu Protokol (İHAS-EP1) m. 3’ün Resmî Gazete'de yayımlanan resmî çevirisi şu şekildedir:

"Yüksek Âkid Taraflar, teşriî organın intihabı hususunda halkın kanaatinin serbest olarak izharın sağhyan şerait dâhilinde uygun ${ }^{11}$ sürelerle gizli oyla serbest seçimler yapmayı taahhüt ederler".

Diğer birçok maddedeki "herkes" veya "hiç kimse" eksenli formüllerin aksine, "Yüksek Âkid Taraflar ... taahhüt ederler" ifadesiyle, devletin pozitif yükümlülüğünü önceleyen sui generis bir niteliktedir ${ }^{12}$. İHAM kararlarında da aynı vurguya rastlanır ${ }^{13}$. Ancak bu vurgu, dönemin uluslararası hukuk paradigmasının (sözleşmenin haklar konusunda ancak devletleri taahhüt altına sokabileceği, doğrudan yurttaşları bağlayamayacağı) yansıması olarak da değerlendirilebilir.

Şu hâlde devlet, siyasal haklarda genel olarak müdahâle ve dolayısıyla ihlâlden kaçınma ile yetinmesine karşın (negatif yüküm, saygı yükümlülüğü), serbest seçimi güvencelemede tedbir almak ve uygulamak zorundadır (pozitif yüküm, gerçekleștirme ve koruma). AYM’nin bir kararında da, bu konu açıkça dile getirilir ${ }^{14}$.

10 Harris \& Q'Boyle, et.al. (n 7) 741.

11 İHEB'de "devrevî", İHAS’ta ise "uygun" sözcükleri geçer. Söz konusu iki belgeden, "makûl aralklarla seçim" ilkesi anlaşılır. Kanımızca bu, demokrasinin en başta gelen kurucu unsuru olan seçimin de asıl gereğidir. Abdullah Sezer, 1982 Anayasası Ekseninde Türev Kurucu İktidar Yetkisinin Sinırları ve Yargısal Denetimi (Doktora tezi Marmara Üniversitesi Sosyal Bilimler Enstitüsü 2006) 570. Makûl süreye uymayan çok kısa veya çok uzun süreler, m. 3 ’ün amacı ile çelişir. Örneğin, 2 yllda bir seçim siyasete ilgisizlik yaratıp etkililiğini yitirmesine neden olabileceği gibi, 10 yllda bir seçim de periyodik siyasal denetim ve hesap verebilmeyi anlamsız kilar.

12 IHHAS-EP1 m. 3’ün 2 özelliği vurgulanır: İlki, maddenin "olağandışı tasarımı"dır. Zira madde, bireye doğrudan hak vermek yerine, devlete genel bir yükümlülük yükler. İkinci olarak, İHAM’ın bu alanda bireysel özgürlüklerin geliştirilmesini üstlenmek ile taraf devletlerin söz konusu yükümlülük bağlamında seçimlerle ilgili düzenlemeleri gibi oldukça hassas siyasî bir konuya bir ulusal-ötesi mahkeme sıfatılla karışmadaki geleneksel isteksizliği arasında bir denge kurması gerekir. Harris \& Q’Boyle, et.al. (n 7) 735. Konu, özellikle seçim sistemleri ve seçim barajı yönüyle hâlâ büyük ölçüde takdir marjı içinde görülmeye devam etmektedir. Ancak, - vicdanî ret örneğinde olduğu üzere - üye ülkelerin tercihleri sonrası oluşan konsensüs kendiliğinden ortak Avrupa standardına dönüştüğü takdirde, IHHAM’’n yaklaşımının değişmesi ve ihlâl kararları vermesi de kuvvetle muhtemeldir.

13 İHAM Mathieu-Mohin \& Clerfayt v. Belgium, App. No. 9267/81, Judg. 02.03.1987, § 48-54.

14 "Serbest seçim ilkesi seçmenin hiçbir müdahaleye, baskıya ve etkiye kapılmadan oyunu kullanmasın ifade eder. Oyunu kullanacak seçmenin özgür iradesine yönelik her tür etki, baskı sayllir. Seçmeni dolayl da olsa, olumlu ya da olumsuz etkileyebilecek her türlü girişimin önlenmesi gerekir. Vatandaşların oy hakkın Anayasänn öngördüğ̈̈ ilkelere uygun olarak kullanmaların sağlamak devletin yükümlülüğüdür". AYM, E. 2018/69, K. 2018/47, K.T. 31.05.2018. Ancak Mahkeme, "sandık taşıma" kararında, "[k] ural, YSK'ya seçmenin oyunu kullanacağı sandiktan daha uzak mesafede bulunan bașka bir sandikta oy kullanmasına yol açabilecek nitelikte bir yetki verdiğinden bu yetkinin kullanilmasının oy hakkının sintrlanması sonucunu doğuracağı açıtır" görüşünü ortaya koysa da, nihayetinde bu sınırlamayı 1 karşı oya rağmen Anayasảya uygun bulmuştur. 
Sonuç olarak, İnsan Hakları Avrupa Sözleşmesi (IHAS) sisteminde seçme hakkının güvencelenmesi 2 ilke açısından ciddî önem kazanır: Devletin yükümlülüğü, seçilme hakkına nazaran daha güçlü koruma. Ancak İHAM, bazı konularda hakları "geliştirici” işlevinden uzaklaşmaktadır".

\section{B. YAŞ ŞARTI AÇISINDAN ÖN SAPTAMALAR}

\section{Yaş şartı, genel oy ilkesinin istisnasıdır}

Örn. 1982 Anayasası̉nda, oy hakkına ilişkin ilkeler sayılır:

"Seçimler ... serbest, eşit, gizli, tek dereceli, genel oy, açık sayım ve döküm esaslarnna göre, yargı yönetim ve denetimi altında yapıllı"' (m. 67/2, c. 1).

Yaş boyutu itibariyle kişi bakımından sınırlama, bu ilkelerden genel oyun bir istisnasıdır. Esasen "genel oy" bakımından ideal olan, herkesin oy kullanmasıdır. Ancak, haklı ve makûl gerekçelerle genel oya getirilen istisnalar, "sinırlı oy"u doğurur.

İşte bu makûl nedenlerden biri de yaş şartıdır. Aynı husus, BM İnsan Hakları Komitesỉnin 25 no.lu genel yorumunda da sıkça geçer ${ }^{16}$.

Her hak ihlâli müdahâle oluşturmasına karşın, her müdahâle/sınırlama/istisna bir ihlâlyaratmayabilir. Zira, istisna yasal, nesnel, haklı, meşrû ve makûl nedene dayanmakta ise, bu nedenle bireye uygulanan somut müdahâle de o hakkın ihlâli sonucunu doğurmaz. Bunun gibi, bireyler arası farklılaştırma da, her zaman ayrımcı nitelik taşımayabilir. Farklı muamelenin ayrımcı olarak nitelenebilmesi için, makûl bir gerekçeye dayanmıyor olması gerekir ${ }^{17}$.

15 Örn. İHAM, ulusal ve uluslararası hukuk belgelerinin devletlere yurt dışında yaşayan seçmenin oy kullanma hakkını güvenceleme yükümlülüğü getirmediği ve ayrıca Avrupa Konseyi üyesi ülkelerde o dönem için yeterli bir konsensüs oluşmadığı kanısından hareketle, konuya ilişkin bir başvuruyu İHAS-EP1 m. 3’ün ihlâli olarak değerlendirmemiştir. Sitaropoulos \& Giakoumopoulos - Yunanistan, Büyük Daire, K.T. 15.03.2012. Akt. Doğru \& Nalbant (n 9) 819-820.

16 BM-İHK, 25 no.lu genel yorum, 1996, $\$ 4$ : "Yurttaşların bu haklardan faydalanabilmesi yasal olarak belirlenmiş, objektif ve makul olan sebepler dışındaki sebeplerden ötürü askıya alınamaz veya kısıtlanamaz. Örneğin, zihinsel yetersizlik, oy kullanma veya kamu hizmetine girme hakkın kısttlama nedenlerinden biri olarak görülebilir". Lema Uyar, Birleşmiş Milletler'de İnsan Hakları Yorumları: İnsan Hakları Komitesi ve Ekonomik, Sosyal ve Kültürel Haklar Komitesi 1981-2006 (İstanbul Bilgi Üniversitesi 2006) 76. \$10: "Seçimlerde ve referandumlarda oy kullanma hakkı yasalarla tanınmalıdır ve bu hak sadece oy kullanmak için belirli bir yaş sinırının öngörülmesi gibi makul nedenlerle sinırlandırılmalıdır". ibid 78. \$15: "Seçilme hakkına sahip olmayı engelleyen asgari yaş sinırı gibi kısıtlamalar objektif ve makul kriterlere dayandırılmalıdır". ibid 79.

17 BM-İHK, referandumda oy hakkında 10 yıllık ikamet şartına ilişkin başvuruda, şu görüşü ortaya koyar: "Komite, nesnel ve makul ölçütlere dayanması ve amaçlanan hedefin Sözleşme tarafindan meşru sayılması kaydıyla, farklılaştırmaların ayrımcilğa yol açmayabileceğini hatırlatmaktadır". BM-İHK kararı, Marie-Hélène Gillot vd. v. Fransa, Başvuru No. 932/2000, K.T. 15.07.2002, \$ 13.5 Akt. Raija Hanski \& Martin Secheinin (Der.), İnsan Hakları Komitesinin Emsal Kararları Çev. Defne Orhun (Bilgi Üniversitesi 2005) 584. 


\section{Yaş, seçme hakkının olumlu şartlarındandır}

Seçmen olmanın 2 kategori şartı mevcuttur:

- Olumlu şartlar: Varlığı aranan, olması istenen şartlardır. Örn. Vatandaşlık, yaş, vs.

- Olumsuz şartlar: Olması istenmeyen durumlardır. Örn. Kısıtlılık, hükümlülük, vs.

Buna göre, konumuz olan seçme yaşı, olumlu şartlardan biridir ${ }^{18}$.

\section{Yaş şartının nedeni asgarî olgunluk ve sorumluluktur}

Siyasal haklarda aranan yaş sınırı, belli ruhsal olgunluk ve sorumluluk düzeyini gösterir ${ }^{19}$.

Bir yazar, yaş ölçütünü bu konudaki insan doğasına en uygun, en kolay, en kestirme ve belki de en az sakınca yaratacak ölçüt olarak niteler ${ }^{20}$. Yaş sınırının ardındaki belli bir olgunluğa erişme şartı İHAM kararlarında da geçer ${ }^{21}$.

Seçmen yaşına, "medenî rüşt"ten farklı olarak "siyasî rüşt" denir 22 . Siyasî rüştle, "kişinin, ancak, bu yaşta, oy kullanırken ulusal istencin oluşumuna katkıda bulunabilme bilincine eriştiği varsayılır"23. $\mathrm{Bu}$ gerekçenin de etkisiyle, bazı ülkelerde evliler için seçmen şartı daha düşüktür.

\section{Dünya'da seçme yaşı, I6-2I arasında değişmektedir}

Bu konuda birçok detaylı çalışmayı bir araya getiren veritabanları olsa da, güncel verilere ulaşmak oldukça zordur ${ }^{24}$. Bazı istisnaî örnekler ${ }^{25}$ bir yana bırakılacak olursa, baskın sayıda ülkede genel ve yerel seçimlerde yaş sınırı aynı olduğu için, seçme yaşını parlamento seçimleri üzerinden değerlendirip, bazı dikkat çeken yönlere değineceğiz.

18 Abdurrahman Eren, Anayasa Hukuku Dersleri (3. Bası Seçkin 2021) 366; Kemal Gözler, Türk Anayasa Hukuku (2. Bası Ekin 2018) 484; Hatice Derya Ormanoğlu, Demokratik Sistemlerde Temsilde Adalet ilkesinin Gerçekleştirilmesi (Doktora Tezi Hacettepe Üniversitesi Sosyal Bilimler Enstitüsü 2019) 175.

19 Bahri Savcı, 'Seçmenlik Şartları Bakımından Seçim Rejimi' (1947) 2/3 Ankara Üniversitesi Siyasal Bilgiler Fakültesi Dergisi 228; Eren (n 18) 366. Ancak, bu yaşın söz konusu gerekçeden hareketle çok yüksek tutulması da, genel oy ilkesi ile çelişir. Ömer Anayurt, Anayasa Hukuku: Genel Kısım (3. Bası Seçkin 2020) 495.

20 Savc1 (n 19) 228.

21 İHAM, Hirst v. United Kingdom (No. 2), Grand Chamber, App. no. 74025/01, Judg. 06.10.2005, § 62. Ayrica bkz. Harris \& Q’Boyle et.al. (n 7) 741; Doğru \& Nalbant (n 9) 819.

22 Karamustafaoğlu (n 4) 171; Eren (n 18) 366; Ayhan Döner, Türk Anayasa Hukuku (Yetkin 2021) 227.

23 Yılmaz Aliefendioğlu, 'Temsili Demokrasinin 'Seçim’ Ayağı' (2005) 60 Türkiye Barolar Birliği Dergisi 77.

24229 ülke ve territory'de seçme yaşı için bkz. CIA Factbook: https://www.cia.gov/the-world-factbook/field/suffrage (erişim tarihi: 14.11.2021). 240 ülke ve territory'de seçme yaşı için ayrıca bkz. 'Voting age: What is the legal voting age in the national elections?', The Electoral Knowledge Network, https://aceproject.org/electoral-advice/archive/questions/ CDTable?question=ES004\&view=country\&set_language=en (erişim tarihi: 11.03.2021).

25 Örn. Almanya'da genel yaş 18 olsa da, bazı federe devletler ve belediye seçiminde 16'dır. İsrail'de genel yaş 18, belediye seçiminde 17'dir. Suudî Arabistan'da parlamento seçimi olmayıp, seçimler yalnızca belediye içindir. 
En düşük genel seçme yaşı $16^{3} \mathrm{~d} ı^{26}$. Buna karşın, - Birleşik Arap Emirlikleri’ndeki 25 yaş ${ }^{27}$ ve Vatikan örneğindeki 80 yaş ${ }^{28}$ bir yana bırakılırsa - en yüksek yaş $21^{\prime} \mathrm{dir}^{29}$.

Bazı özel yapılarda ise, bağlı ülkelerde seçmen yaşı ayrı düzenlenir. Örn. Birleşik Krallık’n parçalarından İngiltere ve Kuzey İrlanda’da 18, İskoçya ve Galler'de 16'dır ${ }^{30}$.

16 yaşın kabûl edildiği bağımsız devletlerin birçoğu anlamlı örnekler olsa da, bağımlı alanlar ve denizaşırı topraklar (diğer territory'ler) açısından aynı şeyi söylemek zordur. Zira bazılarında gerek nüfus sayısı ve milletvekili sayısı çok düşük olduğu için, yaşı düşürme bir bakıma zorunluluktan kaynaklanır ${ }^{31}$. Buna karşın, en yüksek yaş uygulayan bazı bağımlı topraklarda ve bağımsız devletlerde de meclis üye sayısı 100'ün altındadır ${ }^{32}$.

Bazı ülkelerde seçme yaşının asgarî alt sınırı herkes için aynı iken, bazı ülkelerde "kademeli seçmen yaşları" söz konusudur. En sık rastlanan ölçütler ise, çalışma ve evliliktir ${ }^{33}$.

Bazı ülkelerde, seçme yaşı ancak referandumla değiştirilebilir. Danimarkảda tercih Anayasa ile kanuna bırakılmış ve kanunla 18 olarak belirlenmiş olup, ancak referandumla değiştirilebilìr ${ }^{34}$. Ancak, konuya temkinli yaklaşmakta yarar bulunduğu ve hakkı geriye götürücü bir değisşikliğin referanduma sunulmasının tartışılabilir olduğunu not düşelim.

26 Bu ülkeler 3 gruptur: 1) Genel olarak 16 yaş: Avusturya, Brezilya, Küba, Guernsey, Jersey, Isle of Man, Nikaragua. 2) Sadece çalışanlar için 16 yaş: Sırbistan, Bosna-Hersek, Slovenya. 3) Sadece evliler için 16 yaş: Macaristan, vb. (S Carrie Seleman, 'Around the World: Children's Suffrage: Giving 16 Year Olds the Right to Vote' (2018) 38/2 Article 8 Children's Legal Rights Journal 174-175. https:/lawecommons.luc.edu/clrj/vol38/iss2/8 (erişim tarihi: 11.03.2020); CIA Factbook passim.

27 Birleşik Arap Emirlikleri’nde Majlis al-Ittihad al-Watani adlı tek kanatlı heyet, parlamento olmayıp, seçim dışı karma usulle belirlenir: Monark tarafından atanan 20 üye ve seçiciler kurulunca dolaylı yoldan seçilen 20 üyeden oluşur. Sezer Demokrasi Teorisi ve Pratiğinde Seçim Barajları (n 3) 96.

28 Vatikan’n seçilen parlamentosu yoktur. Devlet Başkanı olan Papa'yı 80 yaşını aşmış kardinaller seçer.

29 Kuveyt, Lübnan, Umman, Samoa, Singapur, Solomon, Tokelau, Tonga, vb. Malezyàda ise 2019'da 21'den 18'e indirilmiştir.

30 Neil Johnston \& Elise Uberoi 'Voting Age' (2020) 1747 House of Commons Library Briefing Paper 19 November 20205.

31 Örn. her üçü de Birleşik Krallıka bağlı olan 3 deniz aşırı bağımlı ülkeden Isle of Man parlamentosu 24, Guernsey parlamentosu 45, Jersey parlamentosu 58 üyelidir. Sezer Demokrasi Teorisi ve Pratiğinde Seçim Barajları (n 3) 95.

32 Örn. Yeni Zelanda’ya bağlı Tokelau’da, General Fono adlı parlamento, 20 üyelidir. Sezer Demokrasi Teorisi ve Pratiğinde Seçim Barajları (n 3) 95, CIA Factbook: passim. Samoa’da Fono adlı parlamento 49 üyelidir (CIA Factbook: passim). Solomon parlamentosu 50 üyelidir. Hatta Umman bağımsız devlet olsa da, parlamentosu 83 üyelidir. Sezer Demokrasi Teorisi ve Pratiğinde Seçim Barajları (n 3) 72.

33 Örn. Bosna-Hersek, Sırbistan ve Slovenya’da seçmen yaşı 18 iken, çalışanlar için 16'dır. Macaristan'da olağan yaş 18 iken, evliler için 16'dır. Endonezya'da olağan yaş 17 ve Dominik Cumhuriyeti’nde 18 iken, evliler için yaş sınırı yoktur (CIA Factbook passim).

341953 Danimarka Anayasası m. 29/2: "Seçme ve seçilme yaşı, 25 Mart 1953'te referandumda kabul edilen yaş sinırıdır. Bu yaş sinırı yasayla değişstirilebilir. Millet Meclisince kabul edilen yaş sinırın değiştiren yasa teklifini, Kral, ancak m. 42/5'te belirtilen referandumda kabul edildikten sonra onaylanabilir". AB Üyesi Bazı Ülkelerin Anayasaları (Adalet Bakanlığ1 2011) 157. Ayrıca bkz. https://www.constituteproject.org/Denmark_1953 (erişim tarihi: 14.11.2021). 


\section{YAŞ AÇISINDAN EŞiTLIK VE IDEAL ILKELER DENEMESi}

Yaş şartının belirlenmesinde eşitlik ilkesinin yaşama geçirilmesinde bazı ideal ilkeleri saptamayı deneyeceğiz. Seçmen yaşı açısından ortaya konulan tercihler bu ilkelere dayanmalıdır.

\section{A. MAKÛL BIR SINIR OLARAK YAŞ}

Demokratik devlet açısından sine qua non öğe olan seçme hakkı, bu bağlamda asgarî şartlardan biridir. Serbest seçim hakkı, etkili ve sürdürülebilir bir demokrasi açısından önemlidir. Bu bağlamda hak, birey-devlet arasında köprü kurmanın birincil aracıdır. Ancak, bu haklar mutlak olmayıp, zımnî kısıtlamalar mevcuttur (doğal, nesnel, içkin).

Seçme hakkı, bazı açılardan doğal sınırlara sahip olup (sınırlılık), bir kısmı Anayasa ve kanunlar başta olmak üzere mevzuatımıza da yansımıştır:

- Kişi bakımından: Her birey, seçme hakkını kullanamaz. Yaş, makûl sınırların ilkidir. Örn. 5 yaşındaki bireyin oy kullanamaması, bütün ülkelerde ortak bir kabûldür. Zihinsel yeterlilik diğer bir makûl şarttır. Seçme hakkının doğumla kazanılması yönünde öneriler de gözlenir (Almanya'da Yeşiller girişimi).

- Yer bakımından: Seçmen, oy hakkını istediği yerde kullanamaz. Oyunu bir yandan kendi ülkesi için, öte yandan kural olarak kendi ülkesinde veya yurt dışında ise belirlenen mekânda kullanır. Yer bakımından sınırlılık, yerel seçimde daha önem kazanır. Zira seçmen, istisnaî hâller hariç istediği yerde değil, kural olarak ikamet ettiği yer için ve o yerde oy kullanır.

- Zaman bakımından: Seçmen, her istediği anda bu hakkını kullanmak için ortaya seçim sandığının konulmasını talep edemez. Zira bu hak, birçok haktan farklı olarak, seçimlerde periyodik olarak, referandumlarda ise belli zamanlarda kullanılabilir.

- Konu bakımından: Seçmen, her istediği konuda ve her türlü iradesinin ilgili merciler tarafından dikkate alınarak uygulamaya konulmasını isteyemez. Ancak mevzuatla düzenlenen konularda ve gerekli şartlar oluşursa seçim veya referanduma katılabilir. Örn. hâlihazırda ülkemizde kanunlar referanduma sunulmadığı gibi, anayasa değişikliği de ancak belli şartlarda sunulabilir. Öte yandan, hâlihazırda örneğin AYM üyelerini de seçemez.

- Koşullar ve diğer usûlî gereklilikler bakımından: Seçmen, oy kullanırken bazı usûli şart ve gerekliliklere uymalıdır. Örn. kayıtlarda yer alan seçmen olduğunu resmî belge ile kanıtlama, oyunu kullandığına dair imza, mükerrer oy kullanımını önleyici tedbirler, vs.

Diğer bir saptama ise, hakkın kullanım sistemi açısından yapılmalıdır. Bilindiği üzere, teoride hakların kullanılmasında birçok sistem geçerlidir: Serbestlik, bildirim, izin. Seçme hakkının kullanılmasında aslolan serbest oy olsa da, geçerli olan usûl şarta bağlı kullanımı içerir. Zira Ancak, özellikle zaman bakımından geçerli olan periyodik kullanım dikkate alınınca seçmenin bu hakkını istediği anda kullanamayacağı açıktır. 
İHAS sisteminde her hak ve özgürlük, kural olarak sözleşmenin ilgili maddesinde belirtilen sebeplerle sınırlandırılır. Ancak güvence altına alınan haklara ilişkin olarak genel bir sınılama nedenleri listesi olmadığı gibi, dahası ilgili maddede de (İHAS-EP1, m. 3) somut bir sınırlama nedeninden bahsedilmez. Ne var ki, genel veya özel sınırlama sebebine yer verilmemiş olması, hakkın sınırsızlı̆̆ı anlamına da gelmez. Zira bu tür haklar mutlak olmayıp, zımnî sınırlamalara tâbidir ${ }^{35}$.

Nitekim bu bakış, İHAM Büyük Daire’nin Ždanoka v. Latvia ve Yumak \& Sadak v. Turkey kararlarındaki yorumlara da yansır: İHAS-EP1 m. 3’te, İHAS m. 8-11 arası maddelerde olduğu gibi sınırlamayı haklı kılan meşrû amaçların belli bir listesi olmadığı için, belirtilen amacın hukukun üstünlüğü ilkesi ve İHAS'ın genel hedefleri ile bağdaştığının davanın kendine özgü koşullarında kanıtlanması şartıyla, devletler 8 ilâ 11 arasındaki maddelerdeki meşrû amaçlar dışında bir amaca dayanabilir. Dolayısıyla, m. 8-11'de yer alan "gereklilik" veya "zorlayıcı toplumsal ihtiyaç" ölçütlerinin, seçimlerle ilgili haklara getirilen sınırlamaları incelerken kullanılamayacağı belirtilir. Ayrıca, m. 3’e uygunlukta aranan standartların, İHAS m. 8-11 çerçevesinde uygulanacak standartlardan daha gevşek olduğu saptanır ${ }^{36}$. $\mathrm{Ne}$ var ki bu durum, devletlerin sahip olduğu geniş takdir marjının sınırsız olduğu biçiminde yorumlanamaz. Taraf devletler, söz konusu hakkı, 1 No.lu Ek Protokol m. 3'ün amacıyla çelişmeyen şart, prosedür ve sınırlamalara tâbi tutabilirler. Bu sinırlamaların İHAS'la uyumunu test etmek ve bu konuda nihâi kararı vermek ise, İHAM’’n yetkisi dâhilindedir. Buna göre müdahale meşrû amaç izlemeli, ölçülü olmal, "yasama organmmn seçiminde halkın kendi düşüncelerini serbestçe ifade etmesi"ni engellememeli ve hakkın özünü zedelememelidir ${ }^{37} .1982$ Anayasasinda ise, -daha sonra "Sonuç" kısmında değineceğimiz üzere- m. 13. güvencelerinin (örn. ölçülülük, hakkın özü) getirdiği koruma devam etmektedir.

İHAS bağlamında taraf devletler, bu doğrultuda kendilerine tanınan geniş takdir payı çerçevesinde, minimum yaş şartı öngörebilirler ${ }^{38}$. Ancak, meşrû bir nedene dayanmayan yüksek yaş sınırı uygulamaları seçme hakkının ihlali olarak görülecektir ${ }^{39}$. Bu sorunun İHAM’da sınırlı sayıda karara konu olduğunu da eklemek gerekir ${ }^{40}$.

Ayrıca, BM Medenî ve Siyasî Haklar Sözleşmesi m. 25/(b)'de benzer hüküm geçer:

"Her yurttaş, 2. maddede belirtilen ayrmlara ve makul olmayan kıstlamalara bağh olmaksızın: a) Doğrudan doğruya ya da özgürce seçilmiş temsilciler aracilı̆̆ ile kamu yönetimine katılma; b) Genel, eşit ve gizli oyla belirli dönemlerde yapılan, seçmenlerin iradelerini özgürce ortaya koymalarını garanti eden gerçek seçimlerde oy kullanma ve seçilme; ... hak ve firsatina sahiptir".

35 Harris \& Q'Boyle et.al. (n 7) 737; Şirin (n 6) 319.

36 Harris \& Q’Boyle et.al. (n 7) 737-738.

37 Doğru \& Nalbant (n 9) 818.

38 Gizem Yardımcı, Avrupa Insan Hakları Mahkemesi Kararlarıla Serbest Seçim Hakkı (Yüksek Lisans Tezi Ankara Üniversitesi Sosyal Bilimler Enstitüsü 2021) 72.

39 Olgun Akbulut, 'Serbest Seçim Hakkı' Ed. Sibel İnceoğlu İnsan Hakları Avrupa Sözleşmesi ve Anayasa (Avrupa Konseyi 2013) 547.

40 Bu konuda bkz. Şirin (n 6) 326. 
Dolayısıyla, oy hakkı, "mefhum-u muhâlifi"nden hareketle, "makûl nedenler"e bağlı olarak sinırlanabilecektir.

\section{B. IDEAL ILKELER DENEMESI}

\section{Medenî ve siyasî rüş̧ yaşını eşitleme}

İlkin belirtelim ki, medenî ve siyasî rüşt yaşı aynı olmalıdır. Böylelikle, medenî hakları kullanma açısından öngörülen yaş ile ülkenin geleceğini belirlemeye ilişkin bir katkı olan seçme hakkı arasındaki çelişkiler de giderilmiş olur.

Ancak mutlaka farklılaştırma yapılacaksa, seçilme yaşı daha yüksek belirlenir. Aksi tercih ise tutarsız olup, makûl bir nedene dayandırılması da oldukça güçtür. Nitekim bu kıyaslama, BM İnsan Hakları Komitesinin (BM-İHK) 25 no.lu genel yorumuna da yansir ${ }^{41}$.

\section{Seçim türüne göre yaş şartını eşitleme}

Seçim türüne göre ayrım yapmaksızın tek bir seçme yaşı belirlenmelidir. Diğer bir deyişle, yapılan tüm seçimlerde (örn. parlamento, devlet başkanlığı, belediye, muhtarlık, vb.) aynı yaş uygulanmalıdır. Bu bağlamda, özellikle 1950 öncesinde farklı seçimlerde farklı yaş tercihlerinin ciddi tutarsızlıklar yarattı̆̆ 1 unutulmamalıdır ${ }^{42}$.

1960'ta yayınlanan bir seçim kanunu şerhinde de detaylıca anlatıldığ üzere, seçme ve seçilme yaşı 1950'li yıllarda da farklı seçimlere ilişkin kanunlarda düzenlenir: Milletvekilleri Seçimi Kanunu (m. 7-9), Belediye Kanunu (m. 23), İdare-i Umumiye-i Vilâyat Kanunu (104) ve Şehir ve Kasabalarda Mahalle Muhtar ve İhtiyar Heyetleri Teşkiline Dair Kanun (m. 7). Yazarın vurguladığı üzere, bu kanunlarda "seçmenlik yaşı 18 veya 22 olarak değişmekte" olup, ayrıca diğer "şartların bir birini tutmamakta olduğu kolaylıkla görülür"ł3.

Hatta bırakınız farklı seçimlerde farklı yaş belirlemeyi, daha büyük sorun, oy hakkının belli seçimlerde tanınmamasıdır. Bu sorun da ülkemizde yaşandı. Nitekim, kadınlar için 1930 ve 1934 te sırasıyla belediye ve köy kanunları ile tanınan hakka karşın, seçme hakkının daha önemli boyutu olan yasama seçiminde oy kullanma hakkı için birkaç yıl daha beklemek gerekmiştir.

41 BM-İHK 25 no.lu genel yorum, 1996, $\$$ 4: "25. madde ile korunan haklarla [katılma, seçme ve seçilme] ilgili olarak öne sürülen her şart, objektif ve makul kriterlere dayanmalıdır. Örneğin, seçilmek veya belirli bir göreve atanmak için, seçme hakkı kullanılırken öngörülen yaştan daha büyük bir yaş sınırı belirlenebilir”. Uyar (n 16) 76.

42 Somut örnekleri eleştiren bir yazarın 1947'deki makalesine göre, belediye sınırları içinde 18 yaşındaki seçmen Belediye Meclis üyelerini seçerken, İstanbul Belediyesi sınırları dışındakiler 22 yaş üzerinden il genel meclisi üyelerini seçmekteydi. Yazar bunu "garip bir vaziyet" olarak niteliyordu. Sonuç olarak, "bir taraftan 18, diğer taraftan 22 yaşını dolduran seçmenlerin seçtiği mümessiller aynı mecliste, 'Ístanbul Meclisinde’ toplanmış olacaktır”. Ayrıca, milletvekili ve il genel meclisi seçiminde yaş şartı 22'yi doldurmak iken, belediye ve köy seçimlerinde 18'di. Savc1 (n 19) 229. 
Bu bağlamda, bazen kitaplarda 1934'te kadınlara seçme-seçilme hakkının tanındığı belirtilse de, bu dikkatsizlik yanlış anlamaya sebebiyet verebilir ${ }^{44}$. Zira bu tarihte bu haklar kadınlara genel seçimde tanınmış olup, diğer birçok seçime katılım zaten daha önce kademeli biçimde tanınmıştı.

Türkiye'de seçimlere ilişkin temel kanunlar arasında birbirine atıflara rastlanmaktadır ${ }^{45}$. Ancak, tüm bunlardan ayrı olarak, Seçimlerin Temel Hükümleri ve Seçmen Kütükleri Hakkında Kanun (STHK), diğer seçim mevzuatı açısından genel bir referans hükmü içerir:

“Özel kanunlarına göre yapılacak Cumhurbaşkanı, milletvekili, il genel meclisi üyeliği, belediye başkanlığı, belediye meclisi üyeliği, muhtarlı, ihtiyar meclisi üyeliği, ihtiyar heyeti üyeliği seçimlerinde ve Anayasa değişikliklerine ilişkin kanunların halk oyuna sunulmasında bu Kanun hükümleri uygulanır" (m. 1).

$\mathrm{Bu}$ bağlamda, ilgili diğer kanunlarda seçme yaşının saptanmamış olması, bir sorun oluşturmaz. STHK m. 1 uyarınca, seçmen yaşı açısından aynı kural uygulanacak olup, bu ise Anayasa m. 67/3'ün yanı sıra STHK m. 6’daki 18 yaşını doldurma şartıdır.

\section{Oy hakkı ve seçme hakkı açısından eşitleme}

Genel olarak halkoylamasını da içeren oy hakkı ve daha dar anlamda seçme hakkına ilişkin yaş da aynı olmalıdır. Bu bağlamda, 1982 Anayasası'nda herhangi bir farklılaşmaya gidilmemektedir. Dünyadaki genel eğilim de aynı yöndedir.

\section{Oy hakkı ve diğer siyasal faaliyetler açısından eşitleme}

Oy hakkı ve diğer siyasal faaliyetlere katılma açısından diğer haklara (parti kurma, üye olma, siyasal faaliyete katılma, vb.) ilişkin yaş şartının eşitlenmesi de doğrusudur. Nitekim 1995 değişikliğiyle m. 67 'de oy hakkı18’e indirilirken, m. 68 de aynı yönde değiştirilmiş ve eşitleme tercih edilmiştir.

\section{Seçme ve seçilme hakkı açısından eşitleme}

Seçme ve seçilme yaşının eşitlenmesi yönündeki tercihin de yaygınlaştığı fark edilmektedir. Nitekim, bu açıdan m. 76'daki farklılığa (18 ve 30 yaş) son verilmesine yönelik anayasa değişikliklerinin aşamalı olarak (2006 ve 2017) ve diğer hususlardan daha sonra gerçekleştiğini eklemekte yarar vardır.

44 "Bu değişiklik ile kadınlara seçme ve seçilme hakkı tanınmıştır". Faruk Yılmaz, Türk Anayasa Tarihi (1808-2010) (İz 2012) 133. Benzer ifade için bkz. Cem Eroğul, Devlet Yönetimine Katılma Hakkı (İmge 1991) 28; Maksut Mumcuoğlu, Çağdaş Demokrasi Kuramlarında Katılma ve Türkiye’de Katılmanın Gelişimi (Doçentlik tezi Ankara Üniversitesi Hukuk Fakültesi 1982) 152; Erdoğan Teziç, Anayasa Hukuku (Genel Esaslar) (21. Bası Beta 2017) 303; Milletvekili Genel Seçimleri: 19232011 (Türkiye İstatistik Kurumu 2012) X.

45 Örn. bkz. Cumhurbaşkanı Seçimi Kanunu, m. 2/2, 2/4; Milletvekili Seçimi Kanunu, m. 42/1, Seçimin Temel Hükümleri ve Seçmen Kütükleri Hakkında Kanun, m. 55/son, Mahallî İdareler ile Mahalle Muhtarlıkları ve İhtiyar Heyetleri Seçimi Hakkında Kanun, m. 18/1(a), 20, 36, vs. 


\section{Yaş şartını kişi açısından ayrımcı uygulamama}

Belirlediğimiz ana ilkeleri tamamlayıcı ilke, herkese, her zaman ve her şartta eşit uygulamadır. Yani, kişi, zaman, konu bakımından ayrıma gidilmemesidir. İlke, “oyun genelliği” ilkesiyle de yakından ilgili, ancak farklıdır. Bu çerçevede, olağan dışı istisnalar bir yana, herhangi bir gerekçe makûl ve meşrû kabûl edilemez.

\section{Yaşı artırmama}

Hukukun dinamik yönü gereği, hiç kuşkusuz, seçme yaşının değiştirilmesi düşünülebilir Ancak değişiklik, yaşı düşürme yönünde, yani hak sahibinin lehine olmalıdır. Osmanlı-Türkiye tarihinde genel eğilim bu olsa da, terk istisnanın 1934’te kadına genel seçimde oy hakkı tanınırken yaşandığını ve ilk kez yaşın yükseltildiğini görüyoruz.

Kaldı ki, yaş yükseltme, sadece o hakkı henüz elde etmemiş “seçmen adayları"na daha yüksek çıta getirme anlamında zorlaştırmadır. Bu ise, haklarda "geriye götürülmezlik" ilkesi olarak adlandırılan ideal ilkeyle çelişir. Ancak, dahası bu tür bir tercih, daha önce oy hakkını kazanmış (ve birçoğu oy kullanmış) kişilerin hakkını da elinden alacaktır. Bu ise, söz konusu ilkenin ötesinde, "hakkı geri almama" ile de çelişecektir.

\section{OSMANLI-TÜRKIYE ANAYASACILIĞINDA SEÇMEN YAŞININ GELIŞiMi}

\section{A. GENEL GELIŞiM}

\section{I877 Talimat-ı Muvakkate: 25 yaş}

Meclis-i Vükelâ (hükümet), ilk Osmanlı anayasasının ilânından 2 ay önce ve ilk seçimde uygulanmak üzere 7 maddelik bir Talimatnâme ${ }^{46}$ çıkardı. İlân edilen Kanun-1 Esâsîde hakkın düzenlenmesi kanuna bırakılmış olup ${ }^{47}$, taşradaki seçimler buna göre yapılacaktı. 1877'de, İstanbul ve çevresi için "Beyanname" adlı hükümet bildirisi yayınlandı.

İstanbul ve çevresinde birinci seçmen olmak için 25 yaşını aşmak ve emlâke mutasarrıf olmak gerekirdi ${ }^{48}$.

46 Meclis Azâsının Sûret-i İntihâb ve Tâyinine Dair Talimât-ı Muvakkate, İ.t. 10 Şevval 1293 (24.10.1876); Düstur, 1. Tertip, C. 4, ss. 2-3. Metin için bkz. Tarhan Erdem, Anayasalar ve Seçim Kanunları (1876-1982) (Milliyet 1992) 135-137.

47 M. 66'ya göre, "Emr-i intihâb rey-i hafî kaidesi üzerine müessestir. Sûret-i icrâsı Kanûn-ı mahsûs ile tâyin olunacaktır". Güncel dille, "Seçim işleri, gizli oy ilkesi üzerine kurulmuştur. Seçimin uygulama yöntemi, özel yasa ile belirlenecektir". Abdullah Sezer, Ulusal-üstü Belgeler ve Önceki Anayasalarla Karşılaştırmalı \& Gerekçeli \& Açıklamalı 1982 Türkiye Cumhuriyeti Anayasası ve İlgili Mevzuat (Beta 2004) 694. Bir diğer güncelleme için bkz. Ahmet Nohutçu \& Ahmet Ziyrek, Osmanl Türk Anayasa Metinleri (Savaş 2020) 19.

48 M. 6: “... Binaenaleyh her dairede o dairenin mütehayyizan ahalisinden mürekkep birer komisyon teşkiliyle o daire ahalisinden ve tebea-i Devlet-i Âliye'den emlâke mutasarrıf olan ve yirmi beş yaşını mütecaviz bulunan zükur ahali mahalleleri itibariyle ayrı ayrı dâvet olunarak Meclis-i Meb’usan için âzâ intihap etmek üzere taraflarından ikişer nefer vekil intihap edeceklerinden..." (Erdem 136). Talimat'taki "mütecâviz", buradaki anlamıyla, "geçen, aşan, fazla, artık, çok" demektir. Mustafa Nihat Özön, Küçük Osmanlıca-Türkçe Sözlük (4. Bası İnkılâp 1988) 582. Ancak bir yazar, 1. ve 2. 
Seçilme yaşı ise Anayasada 30 olarak belirlense de ${ }^{49}$, Talimat'ta 25 olup, az çok emlâk sahibi olma vb. şartlar da vardı ${ }^{50}$. Bu farklılık, ilk cümlede de ifade ettiğimiz üzere, Talimatın Anayasadan daha önce hazırlanmış olmasından kaynaklanmaktadır ${ }^{51}$.

Öte yandan, 1876 Kanun-1 Esâsî gereği ilk meclis açıldıktan sonra hazırlanan seçim kanunu padişahça onaylanmamıştı. 30 yıl sonra seçimler, 1908'de hazırlanan geçici yasa ("Kanun-ı Muvakkat"52) ve uygulamasını gösteren Talimat’a göre yapıldı.

\section{1923: Medenî ve Siyasî Rüştün IIlk Kez Eşitlenmesi}

3 Nisan 1923'te 323 no.lu Kanun'la yapılan değişiklikle, seçmen yaşı 18’e indirildi ${ }^{53}$. Şarttaki “ikmal”den kasıt, 18 yaşını doldurmaktır.

Böylece, - erkeklerle sınırlı da olsa - medenî ve siyasî rüşt yaşının ilk kez eşitlenmesi, olumlu bir adım olarak değerlendirilir ${ }^{54}$.

Ne var ki, değişiklik kanuna aktarılırken, kadınların oy hakkı tekrar Meclis gündemine geldi. Özellikle Hüseyin Avni Bey’in "kadınlar olgunlaşınca oy kullansınlar” meâlindeki yaklaşımı tartışmayı alevlendirdi ${ }^{55}$ :

- Hüseyin Avni Bey (Erzurum): “... Her şeyin bir derecesi, bir vesilei tekemmülü var, ... kadınlar tekemmül edip de, rey hakkını istimal etmek derecesine gelinceye kadar onlar aile efradı beyninde aile reislerine rey vermiş gibi telâkki ${ }^{56}$ edilerek yirmi bin nüfusu zükûrda bir mebus intihabını esas ittihaz etmiştir".

- Tunalı Hilmi Bey (Bolu): "Bilmem, ama böyle bir te’vil akıl ve hayale gelebilir mi?”

seçmen ayrımına girmeden 25 yaşı doldurmaktan söz eder: "... yirmi beş yaşını dolduran, emlâk sahibi erkekler". Fazıl Sağlam, Anayasa Hukuku Ders Notları (Yakın Doğu Üniversitesi Hukuk Fakültesi 2013) 212.

49 Kanun-1 Esâsî m. 68'e göre, "otuz yaşınt ikmal etmeyen" meb’us olamaz.

50 M. 3: "... beynennâs hüsn i siret ve ahlâk ile marûf ve muttasıf ve Devletin lisan-ı resmîsine vakıf olması ve sinnen yirmi beş yaşından aşağı bulunmaması ve müddet-i ömründe hiçbir cinayetle veya politika cünhasiyle mahkûm olmaması ve memleketinde az ve çok emlâk sahibi bulunması şerit-i esasiyeden olmakla sunuf-ı tebea-i Devlet-i Âliye'den bu evsafı câmi' olan her şahsın Meclis-i Meb’usan âzâllğına intihab olunmağa selâhiyeti vardır ve ..." (Erdem 136). Talimat'ta geçen "sinnen" sözcüğü, 25 yaşa girmek veya doldurmak değil, sadece "yaş bakımından, yaşça" anlamındadır. Özön (n 48) 699; Ferit Devellioğlu, Osmanlıca-Türkçe Ansiklopedik Lûgat (Eski ve Yeni Harflerle) (16. Bası Aydın 1999) 1145.

51 Aynı yönde bkz. Servet Armağan, 'Türkiye’de Parlamento Seçimleri' (1967) 3-4/33, İstanbul Üniversitesi Hukuk Fakültesi Mecmuast 50.

52 İntihab-ı Meb'ùsân Kanûn-ı Muvakkatı, İ.t. 20.07.1324 (1908). Metin için bkz. Erdem 138-151. Geçici yasa sonrası birçok talimat, kanun-1 muvakkat, kararname, tebliğ hazırlandı. Bkz. Erdem 152-159.

53 M. 2: "On sekiz yaşını ikmal eden her ferd-i zükûr intihab etmek hakkını haizdir". Erdem 158.

54 Saim Ekici, 1982 Anayasasında Seçme ve Seçilme Hakları (Yüksek Lisans Tezi Ankara Üniversitesi Sosyal Bilimler Enstitüsü 2009) 63.

55 TBMM Zabıt Ceridesi, Devre: 1, İçtima senesi: 4, C. 28, Iç̧tima 18, Celse: 1, T. 03.04.1339(1923)-Salı 329.

56 Alıntılanan metinde, "talakki". 
- Hüseyin Avni Bey (devamla): "Temenni ederim ki, Hilmi Bey ve bütün Heyeti Celile kadınlk âlemimizin - seciyelerinden hiç şüphem yoktur - ilim ve irfanlarını da tekemmül ettirirler. Onların da erkekler gibi bu tarzda din ve diyanetleri ${ }^{57}$ ahkâmı diniyemiz dairesinde tekâmül eder ve onların da reylerine hürmet ederiz".

- Tunalı Hilmi Bey: "Intihabetmek ve edilmek hakkın vermiyorsunuz; fakat kadınları saymıorsunuz da. (Gürültüler)"

- Hüseyin Avni Bey: “... temenni ederim ki, bu hak verilmeden ziyade alnacak bir haktır. Her halde onlar da bu husustaki haklarını kendilerine lâyık gördüğü zaman bizden alılar”.

3. celsede tekrar alevlenen tartışma, şöyle bitmiştir ${ }^{58}$ :

- Tunalı Hilmi: “... Müsaade buyurun arkadaşlar! Analar, bacılara... (Şiddetli patırdılar) Kadınlara intihabedilmek hakkını verin demiyorum. Fakat arkadaşlar, analarımı, bacılarımı.. (Gürültü̈ler)...”

- Emin Bey (Eskişehir): "Hilmi Bey! Milletin hissiyatiyle oynama, milletin hissiyatiyle oynama!"

- Reis: "Efendim beş dakika teneffüs edilmek üzere Celseyi tatil ediyorum. / Hitamı Celse; saat : 4,40"

Nihayet, kabûl edilen kanun metni şu şekildedir: "On sekiz yaşını ikmal eden her ferdi zükûr intihabetmek hakkın haizdir". Metindeki "ferdi zükûr" ise, "erkek birey" anlamına gelir.

\section{I924 Anayasası: Genel seçimde cinsiyet ayrımsız seçme hakkının reddi}

1924 Anayasası müzakerelerinde seçme yaşında değişiklik olmamasına karşın, önemli bir aşamadır. Zira, genel seçimde cinsiyet ayrımsız oy kullanma hakkı önerisi reddedilmiştir.

Temmuz 1923’te, Atatürk'ün, Cumhuriyet’ten 3 ay, kadına genel seçimde oy hakkından 11 yll önce, el yazısı ile Osmanlıca kaleme aldığı Anayasa Taslağı m. 59 şöyle idi: "Yirmi yaşını ikmal etmiş olan herhangi Türk mebusan intihabına iştirak etmek hakkını haizdir" ${ }^{\prime 59}$. Genel ilkeler ise, m. 68'dedir: Gizli oy ("rey-i hafi"), doğrudan ("bilâvasta"), tek dereceli ("bir dereceli usûl") seçim. Ancak söz konusu ilkeler 1924 Anayasası'na yansitılmad.

Anayasa görüşülürken, şu madde önerilmiştir: "Onsekiz yaşını ikmal eden her Türk mebusan intihabına iştirak etmek hakkını haizdir’00. Ancak, oy hakkı yine erkeklerle sınırlı kalmıștır.

57 Alıntılanan metinde, "dinayetleri".

58 TBMM Zabıt Ceridesi, T. 03.04.1339(1923) 341.

59 Mustafa Kemal Atatürk, Teşkilât-ı Esasiye Kanunu (Proje Hâlindedir) 1339-1342 (Boyut 1998) 9. Güncel dilde karşıllı̆̆1 için bkz. Mustafa Kemal Atatürk, Teşkilât-ı Esasiye Kanunu: Ek Kitapçı: Temel Kuruluş Yasası: Türkiye Cumhuriyeti İlk Anayasa Taslağı: Türkçeleştirilmiş Metin (Taslak halindedir) (Boyut 1998) 14.

60 A. Şeref Gözübüyük \& Zekâi Sezgin, 1924 Anayasası Hakkında Meclis Görüşmeleri (Ankara Üniversitesi Siyasal Bilgiler Fakültesi 1957) 109-113; Ergun Özbudun, 1924 Anayasası (Bilgi Üniversitesi (2012) 24. Nitekim Kanun-1 Esasi Encümeni’nin teklifindeki m. 10, "erkek" sözcüğü hariç aynıdır. TBMM Zabıt Ceridesi, Devre: 2, İçtima senesi: 1, C. 7, 
Aslında 1924’te kadına oy hakkı oy birliği ile (“müttefikan”) kabûl edilmiş, ancak sonra fark edilmiştir.

M. 10 okunduktan sonra, oylamada farkında olmadan kabûl edilmiştir. Nitekim Başkan, maddeyi okuttuktan sonra şunları söylemiştir:

"Reis: Maddeyi aynen reyinize vaz’ediyorum. Aynen kabul edenler lütfen el kaldırsin. Aksini reye vaz’ediyorum. Kabul etmiyenler lütfen el kaldırsın. Madde müttefikan kabul edilmiştir”'1.

TBMM Zabıt Ceridesi’nin sayfa görüntüsünün ilgili kısmı aşağıdadır:

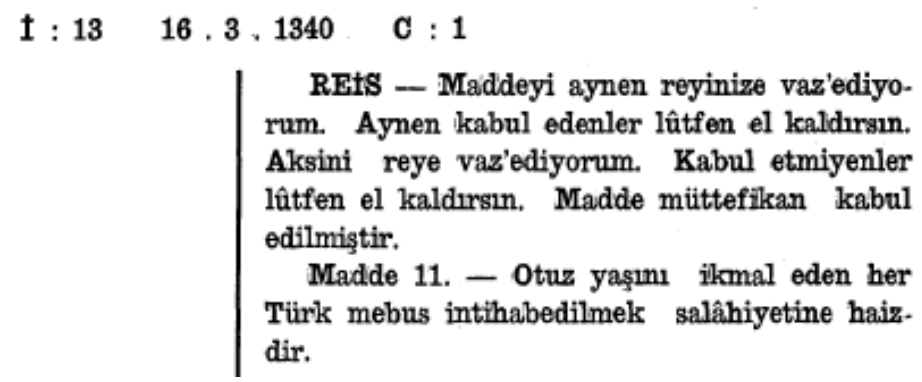

Yukarıdaki sözler resmî tutanağa geçmiş ve itiraz da gelmemiştir. Ne var ki, seçilme hakkına ilişkin m. 11'de durum fark edilerek tekrar tartışılmıştır. İlginç diyaloglardan bazı kesitleri alalım² ${ }^{62}$

- Şefik Bey (Bayezid): "Şimdi onuncu maddeyle kabul edilen esasa göre, her Türk mebus intihabına iştirak hakkını haizdir. (Türk) lâfzının içinde kadınlar da mevcuttur”.

- Refik Bey (Konya): "Onlar da olacaktır”.

- Şefik Bey (Devamla): "Şu halde bunun için istisnai bir şey koymazsanız tabiî kadınlar iştirak eder".

- Feridun Fikri B. (Dersim): "Zaten maksadımız odur, kadınlar da rey verecektir (Alkışlar)”.

- $\quad \ldots$

- $\quad$ Receb Bey (Kütahya): "Efendim, Süreyya Beyefendinin ifadelerinden (Türk) tâbirinin şümulü dâhilinde kadınların olmadiğı anlaşıllyor... Bundan evvelki maddede de bendeniz elimi kaldırırken kadınlar intihaba iştirak etmek hakkını haizdir kanaati mevcudolarak kabul etmiş ve ona göre reyimi vermiştim. (Gürültüler) ... / Efendiler, Türk kadını bu Türk halkının hiç olmazsa yarısı değil midir? Bendeniz bu noktai nazardan Süreyya Beyefendinin ifadelerine muhalif olarak bu - her Türk - kelimesi içinde otuz yaşını ikmal etmiş kadınları da dâhil addederek el kaldırdım Süreyya Bey; yine Intihap Kanununda ısrar buyuruyorlar. Intihap Kanunu ancak bunun noksanın ikmal eden tâli bir kanundur. Asıl kanun, anakanun Teşkilâtı Esasiye Kanunudur. ... ... (Türk) tâbirinden de Türk kadını istisna edilmez".

İçtima 7, Celse: 1, T. 09.03.1340(1924)-Pazar 218.

61 TBMM Zabıt Ceridesi, Devre: 2, İçtima senesi: 1, C. 7, İçtima 13, Celse: 1, T. 16.03.1340(1924)-Pazar 540.

62 ibid 540-543. 
- Mazbata Muharriri Celâl Nuri Bey: "Pek arzu ederiz ki kadınlar da âtide bu hukukunu istimal etsin".

- Receb Bey: "Kadınlar; Türk değil mi beyefendi?"

- Celâl Nuri Bey (Devamla): "Türktür”

- Receb Bey: "Madem ki Türk dediniz. Maddenin şümulü dâhilinde Türk kadını da vardır".

- Reis: "Kadın ve erkek her Türk mebus intihabedilmek hakkına haizdir) bu teklifi reyi âlinize vazédiyorum. Kabul edenler... Lütfen el kaldrrsin, aksini reye vazédiyorum. Kabul etmiyenler lütfen el kaldırsın. Kabul olunmamıştır. (Alkışlar)”.

- Receb Bey: "Kadına hak vermediniz. Bari alkışlamayın yahu!" (vurgular tarafımıza aittir).

İşte bu karmaşanın ${ }^{63}$ ardından, 1924 Anayasası m. 10'un nihaî metni şöyle oldu: "On sekiz yaşını ikmal eden her erkek Türk, meb’usan intihâbına iștirak etmek hakkını hâizdir".

Kurtuluş mücadelesinde en az erkekler kadar etkin rol oynayan kadınların ulusal iradenin oluşumuna katılmaları, böylelikle engellenmişti. Gerçi bu dönemde, kadınlar medenî haklarda (örn. miras, evlenme, boşanma, vb.) ciddi kazanımlar elde etmeye başlamıştı. Ancak, isabetle belirtildiği üzere, siyasal hakların yokluğunda bu tür eşitlik adımları görece etkisiz kaldı ${ }^{64}$.

1926'da, kadınlar Meclis'e, milletvekili olmadan önce memur sıfatıyla girdi. Rukiye hanım, yapılan sinav sonrasında "musahhih muavini" olarak alınd1 ${ }^{65}$.

63 Görüşmeleri değerlendiren Mumcu da, bu belirsizliğe işaret etmektedir: "Seçme hakkını içeren 10. madde aynen kabul edilmişti ve bu durumda kadınlara oy hakkı verilmesi de kararlaştırılmış oluyordu. Madde üzerinde hiçbir tartışma da yapılmamıştı. Milletvekilleri, seçilme hakkını içeren maddeye gelince 'uyandılar'. Kadınlarla ilgili tartışma bașladı. Garip olan durum şudur: Ateşli tartışmalardan sonra 11. maddedeki 'her Türk' ibaresi, 'her erkek Türk' yapılmış, başkan maddeyi böylece oylamış, ama 10. maddeyi tekrar oylamamıştır. Böylece kadınlara seçme hakkı tanınmış oluyordu. Bu 'yanlışlığın' ne zaman düzeltildiğini mevcut yayınlarda bulamadık” (vurgular tarafımıza aittir). Ahmet Mumcu, '1924 Anayasası' (1986) 2/5 Mart, Atatürk Araştırma Merkezi Dergisi 388-389, dp. 19. Benzer görüş için bkz. Bülent Tanör, Osmanlı-Türk Anayasal Gelişmeleri (1789-1980) (4. Bası YKY 1999) 297.

64 Sinem Servet Özdemir, Kadın Hakları Bağlamında Türkiye’de Pozitif Ayrımcılık İlkesi (XII Levha 2019) 23-24.

65 "Müsted'i Rukiye hamının imtihanı icra kılınmış ve merbuten takdim kılınan evrak-ı imtihaniyeye nazaran tensip buyurulduğu takdirde musahhih muavinliği vazifesini ifaya kabiliyeti görüldüğ̈̈nü arz eylerim efendim (İbrahim Sitkı)”. Belge ve özgeçmişin orijinal sayfası için bkz. 90 Yılda 90 Belge (TBMM Genel Evrak ve Arşiv Müdürlüğü 2010) 65 . 
1930'da Belediye Kanunu ile, kadınlara belediye seçiminde seçme ve seçilme hakkı tanındı66. ${ }^{6931 ' d e,}$ bazı sorunlara rağmen ${ }^{67}$ bağımsızlardan ilk kez milletvekili seçildi ${ }^{68}$. 1933'te ise, Köy Kanunu ile, kadınlara muhtar ve ihtiyar heyetlerine seçme-seçilme hakkı tanındı ${ }^{69}$.

\section{1934: ilk gerileme (kadınlar devreye girince I8'den 22'ye)}

1928'de, öğrencisinin “oy kullanamazsin!” tepkisine maruz kalan Afet İnan, Atatürk'ün huzuruna çıkarak kadına genel seçimde oy hakkı tanınmasını rica etmişti. Ancak İnan, konuyu açtığında Atatürk'ün hazırlıksız olduğunu ve 1929'daki yasa değişikliğinde bu gündemin yer almadığını aktariyordu $^{70}$.

Bu adımdan 6 yıl sonra, 1934’te, genel seçimlerde kadınlara seçme ve seçilme hakkı tanınd1 ${ }^{71}$. Önce İsmet İnönü ve 191 milletvekili, Anayasa ve yasa değişikliği teklifi hazırladı. Ancak, kadınlara bu hak

66 Belediye Kanunu, "İtihap etmek şartları" başlıklı m. 23: "Belediye intihaplarında rey sahibi olmak için: 1-Türk olmak, 2-İntihap başlamadan evvel lâakal altı aydan beri beldede ikamet etmekte olduğunu vesaik ile ispat etmek, 3-18 yaşını bitirmiş olmak, ... lâzımdır" (vurgular tarafımıza aittir) (Kanun no. 1580, kabûl tarihi: 03.04.1930; Resmî Gazete, 14.04.1930/1471). Ayrıca m. 24'le, kadınlara da - erkekler gibi - "25 yaşını bitirmiş olmak" kaydıyla ve fazladan bir şart olarak "Türkçe okur yazar olmak" şartıyla "belediye meclisine aza intihap olunmak" (seçilme) hakkı tanındı.

67 Örn. Bağımsız milletvekili adaylığı için çok sayıda müracaat olmasına rağmen bazı yerlerde hiçbir bağımsızın seçilememesi, İzmir'den Halil Bey'in ise 38 oy gibi çok az bir oyla seçilmesinde CHP Yönetmeliğindeki bazı maddeler etkili olmuştur. Kenan Olgun, 'Türkiye’de Cumhuriyetin İlanından 1950’ye Genel Seçim Uygulamaları' (2011) 27/79, Mart, Atatürk Araştırma Merkezi Dergisi 15-16.

68 TBMM Albümüne göre, toplam sayı 20'dir. Ancak 7'si, seçildikten sonra Cumhuriyet Halk Fırkası’na katılmışıtır. TBMM Albümü (1920-2010), C. I: 1920-1950 (TBMM Basin ve Halkla İlişkiler Müdürlüğü 2010) 181.

69 Köy Kanunu’nu (Kanun no. 442, kabûl tarihi: 18.03.1924) değiștiren Kanun, m. 20: "Her köyde bir köy derneği, bir köy muhtarı, bir de ihtiyar meclisi bulunur. Köyde 24 üncü maddeye göre köy muhtarını ve ihtiyar meclisi azaların seçmeğe hakkı olan kadın ve erkek köylülerin toplanmasına köy derneği derler. Köy muhtarı ve ihtiyar meclisi azaları doğrudan doğruya köy derneği tarafindan ve köylü kadin ve erkekler arasindan seçilir...”" (Kanun no. 2329, kabûl tarihi: 26.10.1933; Resmî Gazete, 28 Teşrinievvel 1933/2540). Aynı tarihte değiştirilen m. 30 ise oldukça ilginçtir: "Karı, koca, ana, baba, kız, oğul, gelin, güvey ve kardeşlerin ihtiyar meclisinde aza olarak bir arada bulunmaları yasaktır. Bunların seçilmiş olduğu görülür ise içlerinden en çok sayı kazanmış olan kadın veya erkek azalıkta bırakılır. Sayıları beraber olur ise evli olan, ikisi de evli ise yaşı büyük olan, yaşları da beraber ise çocuğu çok olan tercih olunur. Çocuk adedi de beraber olur ise kur'a çekilerek kurada adı önce çıkan azalı̆̆a alını".

70 Afet İnan, Atatürk'ün Medenî Bilgiler kitabına 14.06.1968'de yazdığı Önsöz'de, o yıllardan hatırasını anlatır: "Bir ders uygulaması olarak, ... Belediye Kanununa göre seçim denemesi yaptırdım. Öğrenciler heyecanla bu işte çalıştılar, oy kutuları hazırladılar. ... bir erkek öğrencinin karşı çıkışı ile karşıllaştım. Diyordu ki: 'Var olan yasanın bize öğrettiğine göre kadınların oy verme hakkı olmadığı gibi, seçilemezler de’, öğrenci karşı çıkışında haklı idi, ... / ... Marmara köşkünde Atatürk ile İçişleri Bakanı Şükrü Kayàya ... Türk kadını olarak oy hakkına sahip olmadığımızdan çok üzüldüğümü anlattım. Atatürk bana bu konuda çalışmamı ve başka ülkelerde bu işlerin nasıl çözülmüş olduğunu incelememi önerdi. ... Atatürk'e şunu söylemekten kendimi alamadım: 'Hiç olmazsa erkek öğrencim kadar bir hak sahibi olmadan o sinıfa ders veremeyeceğim' dedim. ... Atatürk düşünüyordu. Birden 'Başbakan ile konuşuruz, fakat bu konuda hazırlıkl olmak ve tartı̧̧mak gerekir' dedi. ... Mart 1929 tarihinde Başbakan İsmet (İnönü) imzasıyla hükümet teklifi olarak Büyük Millet Meclisi’ne yazılan resmi yazıda ... kadınların oy verme konusu teklif edilmemiştir". Mustafa Kemal Atatürk, Medeni Bilgiler: Türk Milletinin El Kitabı Haz. Ayşe Afet İnan (2. Bası Toplumsal Dönüşüm 2010) 22-23.

71 Ancak kadınlara 3 açıdan sırayla tanınan seçme-seçilme hakları bağlamında bir noktayı özenle ayırmakta yarar var: 1934'te genel seçimde seçme ve seçilme hakkı, doğrudan Anayasa değişikliği ile tanındı (05.12.1934). Oysa, 1930'da belediyelere (03.04.1930, Belediye Kanunu) ve 1933’te muhtarlık ve ihtiyar heyetlerine (26.10.1933, Köy Kanunu) seçme 
tanınırken, daha önce erkekler için konulmuş olan 18 yaşı doldurma şartı da - herkes için geçerli olmak üzere - 22'ye yükseltilmişti.

Meclis’te söz alanlar "kadın zekâsı"nı övdü, eşitlik vurgusu yaptı. Fakat tartışma sadece açık bırakılmış alanlarla mümkün olduğu için, hiçbir konuşmacı yaş yükseltmeye değinmedi:

- Başbakan General İsmet İnönü: "Yüce saylavlar, kadınların saylav seçmek ve saylav seçilmek hakkına sahib olmaları için yüce katınıza teklif sunuyoruz, ... (Okay sesleri ...). / ... Türk kadınının, hakkı olduğu yerden ayrılıb, bir süs gibi, memleket işine karışmaz bir varlik gibi, bir köşeye konması türk annesi ${ }^{72}$ değildir. ....733.

- Refik Bey (Konya): "Ekin kaldırırken, ineğini sağarken, yavrusuna ninni söylerken dahi erkekten ayrılmayan Türk kadını ulus işlerinde de yüksek varlğııı göstermiştir. ... Baylar, sevinelim, Öğünelim, çünkü; Türküz; çünkü Atatürkümüz vardır (Şiddetli alkışlar)"ᄁ4.

- Sadri Maksudi (Şebin Karahîsar): “... âlimler ... kadınların zekâsı tamamile erkek zekâsına müsavi olduğunu ispat etmişlerdir. / Türk zekâsına, Türk kadının zekâsının da katılması ... çok hayırlı"75.

- İsmail Memet (Sivas): "Baylar senelerden beri hizmet ettiğimiz Padişahlardan ... Türk köylüsü, Türk kadın mebusluk hakkı isteseydi mükâfat olarak bizi ya ipe çekerdi ya denize atardı. ... Türk kadınları, Türk köylüleri sizin saadet yollarınız açıktır ve açılmıştır"76.

Sonuçta 5 Aralık 1934’te ${ }^{77}, 258$ milletvekilinin kabûl oyuyla, Anayasa değişikliği gerçekleşti ${ }^{78}$ :

"Yirmi iki yaşııı bitiren kadın, erkek her Türk mebủ seçmek hakkını hâizdir" (m. 10).

Ancak ne görüşmelerde, ne de metnin gerekçesinde, yaş yükseltmenin herhangi bir gerekçesine değinilmedi ${ }^{79}$. TEK Encümeni Mazbatası̉nda da, yaş değişikliğine ilişkin bir cümle yoktu ${ }^{80}$. Fihrist’te

ve seçilme hakkı tanınması, yasalarda yapılan değişikliklerle gerçeklești.

72 Doğrusu, "ananesi" olmalıdır.

73 TBMM Zabıt Ceridesi, 05.12.1934, ss. 82-83.

74 ibid 83.

75 ibid 84 .

76 ibid 84 .

77 Bazı kaynaklarda, 1934 değişikliğinin tarihi 11 Aralık olarak verilse de (Yllmaz 133), bu tarih Kanun’un yayım tarihi olup (Resmî Gazete, 11.12.1934/2877), zaten yazarın asıl kastı da bu olsa gerektir.

78 TBMM Zabıt Ceridesi, 05.12.1934 86. Başkan’ın açıklaması şöyleydi: "18 yaşııı bitirenler kaydı 22 yaşııı bitirenler şeklinde değiştirilmişve ... (Zükûr) [erkek] kaydı kaldırılarak yerine kadın, erkek konulmuştur". ibid 85.

79 "İstibdad ve cehalet devirlerinden arta kalan kötü ve sakat zihniyetlerin ... Cumhuriyet ve inkılâbın temiz ve erdemli muhitinde yeri yoktur. ... Yüksek Türk kadınına mebus seçmek ve mebus seçilmek yolunda da erkeği yanında mevkiini vermeği ve ... yurdunun bütün işlerinde onun temiz duygulu çalı̧̧malarından istifade etmeyi temin etmek için bu kanun teklif edilmiştir" (TBMM Zabıt Ceridesi, 05.12.1934 Ek 2/131).

TBMM Zabıt Ceridesi, 05.12.1934-Çarşamba, C. XXV, Esas No: 2/131, Karar no: 3. 
ise, Ankara Halkevi adına Afet İnan ve arkadaşlarının Meclis’e bizzat giderek ${ }^{81}$ sunduğu teşekkür mektubuna yer verildi ${ }^{82}$.

Tüm bunlara karşın yine de, değişiklik sonrası ilk seçim olan $1935^{\prime}$ te $17^{83}$ kadın milletvekilinin seçilmiş olması önemlidir ${ }^{84}$. Belirtildiği üzere, yüzyıllar boyunca toplumsal-siyasal yaşamdan dışlanmış kadının Meclis’te ve sandık başında görülmesi ileri bir adımdır ${ }^{85}$.

Gerçi teknik açıdan bakınca, esasen bu tarihte ne erkeklerin, ne de kadınların seçme hakkı yoktur. Yurttaş, en yalın hâliyle seçenekler arasında birini tercih etme anlamına gelen seçme hakkını, 1946'da çok partili seçime geçildiğinde kazand. Zira, tek partili rejimlerde "seçme hakkı" veya "oylama hakk»" değil, yalnızca "onaylama görevi” vardır! Ayrıca, 1934’te kadına milletvekili seçme hakkı gelse de, tıpkı erkekler gibi kadınlar da, 2. seçmene oy verdi ${ }^{86}$. Yani, seçim tek dereceli değil, hâlâ 2 dereceli idi. Dolayısıyla bu açıdan da gerçek bir seçim söz konusu değildir.

Sonuç olarak, kadına genel seçimde oy hakkı, 1923 taslağı ve 1924 Anayasası'nın komisyon teklifinde yer almasina rağmen, Anayasa görüşmelerinde tuhaf biçimde reddedildi. Ancak hak, 10 yll sonra bu kez Anayasa değişikliği ile kabûl edildi. Bu gecikmeye karşın, Dünya ile kıyaslandığında 1934 gibi erken bir yılda tanınmış olması kayda değerdir. Ne var ki, yaş yükseltme sorunlu ve onur kırıc1 ${ }^{87}$, en hafif deyimle "geriye doğru bir adım"dır ${ }^{88}$. Hakkın hiçbir mücadeleye girişilmeden alındığına yönelik iddialar ${ }^{89}$ gerçekle örtüşmediği gibi, Afet İnan ve diğer kadınların çabalarına haksızlık ve emeklerine saygısızlıktır ${ }^{90}$. Dahası, kadınların da konuya ilişkin yayınlarında bırakınız tartışmayı, nedenine ilişkin tek bir soru dahi yönelt(e)miyor olması hayli ilginçtir.

81 Afet İnan, Atatürk Hakkında Hatıralar ve Belgeler, yay. haz. Arı İnan (8. Bası İş Bankası 2009) 350.

82 "Türk kadınlarına saylav seçmek ve seçilmek hakkın verdiğinden dolayı Büyük Türk Ulusuna müntehiblerinin bildirilmesini mutazammun Ankara Halkevinde toplanan kadınlar namina mektub" başlıklı belgede şu cümleler yer aldı: "[TBMM] Yüksek Başkanliğına / Dün [BMM] Türk kadınlarının saylav seçmek, saylav seçilmek kanununa onay verdi. Biz Türk kadınları bundan gönenç duyduk. Gerekli olan iş yapıldı. Türk kadını bundan sonra daha eyi anlaşılacaktır. Bu hakikati anlayan, ortaya koyan, kanunla teyit eden Büyük Türk ulusunun mümessillerine minnet”. TBMM Zabıt Ceridesi, C. XXV Fihrist, 1935 20; TBMM Zabit Ceridesi, 06.12.1934 90-91.

83 Bu seçimde TBMM'ye giren kadın milletvekili sayısı, bazı kaynaklarda 15'tir. Kemal Karpat, Türk Demokrasi Tarihi (Timaș 2010) 141; Tevfik Çavdar, Türkiye’nin Demokrasi Tarihi (İmge 1995) 325-326. Bazı kaynaklarda 18 olarak geçer. İnan (n 81) 350; Nur Akdağ, Türkiye Tarihinde İlk'ler (Yeşil Elma 2009) 94-95. Resmî olarak referans yapılabilecek TBMM Albümü'nde de 18'dir (Biyografiler için bkz. TBMM Albümü 239-294). Bunun nedeni şudur: TBMM’nin 5. dönemi için yapılan 1935 seçiminde, 17 kadın milletvekili olarak Meclis’e girdi. 1936'da boşalan sandalyeler için yapılan ara seçimde Hatice Özgener de seçilince, bu sayı 18’e yükseldi (Türkiye İstatistik Kurumu: X).

841935 seçiminin diğer özelliği, ilk defa azınlıklardan milletvekili seçilmesidir. Olgun (n 67) 16; Ülkü Varlık \& Banu Ören, Seçim Sistemleri ve Türkiye’de Seçimler (Der 2001) 80.

85 Mumcuoğlu (n 44) 152.

86 "Ankara'da 40.860 seçmenden 37.542 kadin ve erkek vatandaş, ikinci seçmenlere oy vermiştir". İnan (n 81) 350.

87 "Kanımızca değişiklik, bu yönüyle onur kırıcıdır. Ancak, TBMM’de tartışılmadığı gibi, bu 'aşă̆ılama’ya hakkın muhataplarından da ciddi eleștiri gelmemesi, düşündürücüdür”. Sezer Demokrasi Teorisi ve Pratiğinde Seçim Barajları (n 3) 104.

88 Nitekim bir yazar, kadına genel seçimde oy hakkı tanınmasını "devrimci değişiklik", buna karşın yaş yükseltmeyi ise "geriye doğru bir adım" olarak niteler. Cem Eroğul, Anatüzeye Giriş (15. Bası İmaj 2016) 252.

89 “... daha önce bu yönde verilmiş bir mücadele söz konusu olmamıştır". Teziç (n 44) 303. "1934’te kadınların hiçbir talebi yokken, devletin kararı ile kadınlara seçme ve seçilme hakkı verildi". Karatepe 272.

90 Bu konuda Arı İnan’n yayına hazırladığı bir eserde aktardıkları önemelidir. İnan (n 81) 342-352. 
En azından kadınların, konuya ilişkin yayınlarında bırakınız tartışmayı, nedenine ilişkin tek bir soru dahi yönelt(e)miyor olması hayli ilginçtir. Nadir tepkilerden biri ise, Tanöre aittir:

"1934 tadilleri, kadinları seçme seçilme hakkına kavuşturmuştur. ... Ancak, bu defa da kadınların siyasal rüște erkeklerden geç ulaștıklarına hükmedilmis olacak ki ... kadınlara da bu hakkın tanınmasılla birlikte çıta, 22 yaşını bitirme koşuluna yükseltilmiştir ${ }^{\text {’1 }}$ (vurgular tarafımıza aittir).

1950'de ise, her ne kadar yaşla ilgili bir değişiklik gelmese de, kanunla ${ }^{92}$ gizli oy ve açık sayım-döküm ilkelerinin ilk kez tanındığını ${ }^{93}$, seçme yaşının ise $22^{94}$ olarak saptandığını görüyoruz.

\section{I96I Anayasası: Kanuna bırakma}

Seçme ve seçilme yaşının Anayasa’da gösterilmesi hiç kuşkusuz önemli bir güvencedir. Zira, özellikle kodifiye edilmiş ve katı bir anayasa varsa, olağan yasa yapma çoğunluğu ile değiştirilemeyecek bir güvence söz konusudur.

Oysa 1961 Anayasası’nda bu konu düzenlenmeyip, kanuna bırakılır: "Vatandaşlar, kanunda gösterilen şartlara uygun olarak, seçme ve seçilme hakkına sahiptir” (m. 55/1).

İlgili seçim kanununun Temsilciler Meclisi’ndeki müzakerelerinde ${ }^{95}$, ilk teklifteki 18 yaş 2l'e yükseltildi: "21 yaşını bitiren her Türk seçmendir" (STHK, m. 6).

Türkiye İşçi Partisi eşitlik ilkesine aykırılık savıyla konuyu AYM'ye taşısa da, Mahkeme oybirliği ile reddetmiştir. İlginç nokta, Mahkeme’nin, Anayasảda yaşın düzenlenmemiş olmasının medenî ve siyasî rüşst yaşlarının eşitlenmesi anlamına geldiği savını isabetsiz bulmasıdır ${ }^{96}$.

91 Tanör (n 63) 1999 323-324. Aynı görüşe bir referans için bkz. Varlık \& Ören (n 84) 135-136, dp. 33.

92 Kanun no. 5545, kabûl tarihi: 16.02.1950.

93 M. 1: "Milletvekilleri seçimi tek derecelidir ve ekseriyet usulüne göre geneleşit, gizli oyla yapılır. Oy serbest ve şahsidir. Oyların sayılması ve ayrılması açıktır". Akt. Erdoğan (n 43) 7.

94 M. 2: "Milletvekili seçiminde 22 yaşın bitiren her vatandaş seçmendir". Akt. ibid 28.

95 Muhittin Gürün: "[M]emleketimizde nüfusun \% 70[']i eğitimden geçirilememiştir. Bu bakımdan demokratik ehliyet için eğitim esas alınamıyor. Elimizde kala kala bir yaş unsuru kalıyor. Yaşın seçmen yeterliği verebilecek bir yüksekliğe gelmesini beklemek icabeder. / ... 18 yaş, seçmen yeterliği için kâfi bir çağ değildir. Bilhassa köyde yaşıyan vatandaşlar, ancak askerlik sebebiyle köylerinden dışarı çıkabiliyor”. Temsilciler Meclisi Tutanak Dergisi, B. 25, O. 3, 09.03.1961 583. Nurettin Ardıçoğlu: "Tahsil çağında bulunan gençlere parti münakaşası yaptırmıyalım, seçmen yapmak suretiyle”. ibid 584. İsmet Giritli: “... her reşit olan Türk’ün seçmen olarak ilân edilmesini rica ediyorum. / ... Eğer muhterem heyetiniz 18 yaşın Türk vatandaşı için medenî rüşt bakımından kâfi bir yaş olmadığı kanaatinde ise, o zaman işe Medenî Kanunu tadil etmekle başlamalıdır”. Temsilciler Meclisi Tutanak Dergisi, C. 2, B. 37, O. 3, 04.04.1961 535. Kaludi Laskaris: "18 yaşındaki çocuklarımızı siyaset sahasının patırtıları içerisine atmak benim kanaatime göre iyi bir yol değildir”. ibid 536. Hıfzı Veldet Velidedeoğlu: "Arkadaşlar; bir genç askerliğe gitmeden önce oy vermemelidir". ibid 543.

96 “... Kanunun iptali istenen 6 noı maddesinde (21 yaşını bitiren her Türk seçmendir) denilmektedir. Bunun, ... eşitlikle bir ilgisi olmamak gerekir. Çünki 12 nci maddedeki 'eşitlik' deyimi ile kanun önündeki eşitlik yani hukuki eşitlik kastedilmiştir. Yoksa, bu madde ile yaş farkını gözetmeksizin herkesin ayni hakkı haiz olacağı yolunda tabii bir eşitlik öngörülmemiştir. / İptal isteminde, milletvekili ... ve Cumhuriyet Senatosu Üyeliğine seçilebilmek için ... belli bir yaş kabul edildiği halde, seçmenlik için herhangi bir yaş kabul edilmemiş olmasının, Anayasa’nın, seçmen olabilmek konusunda Medenî Kanun 
1975’te bu kez Of Asliye Ceza Mahkemesi itirazla AYM'ye götürmüş ve yine - ancak 8-7 çoğunlukla - Anayasa'ya uygunluk kararı çıkmıştır ${ }^{97}$.

1978'de kanun tekrar AYM’ye geldi. Yine 8-7 çoğunlukla Anayasa'ya uygunluğun yanı sıra, yaşın indirilmesine herhangi bir engel bulunmadığı vurguland1 ${ }^{98}$. Bir karşı oyda ise, rüşt yaşlarını eşitleme gereği savunuldu99. 1982 Anayasası'nın ilk metninde ise, seçme hakkı, "yirmibir yaşını dolduran her Türk vatandaşı"na tanınmıştı.

\section{1987: 20 yaşına girme}

Anayasa değişikliği ile, seçimlerin yapıldığı yılda, ay ve gün hesaba katılmaksızın, "20 yaşına giren her Türk vatandaşı”nın bu hakka sahip olacağı düzenlendi (Anayasa, m. 67/3).

Değişiklikte, iki husus dikkati çekmektedir. İlkin, mevcut Kanun'un düzenlemesine tamamen karşıt biçimde, seçimin yapılacağı yılda kişinin doğduğu ay ve gün hesaba katılmayacaktır. İkinci olarak, diğer kurallardaki gibi belli bir yaşı "dolduran” değil, belli bir yaşa "giren” kişi bu hakkın süjesi olabilecektir. Dolayısıyla değişiklik, her iki açıdan genel tercihlerden farklı gibi görünse de, asıl sapma ilk özelliktir. Zira, ikinci açıdan ortaya çıkan farklılıkta, bir yaşı “doldurma” şartının sonraki yaşa "girme" ile - aynı olmasa dahi - yakın anlama geleceği belirtilebilir.

uyarınca reşit olmayı yeterli saydiğına delâlet eylediği yollu ileri sürülen gerekçede isabet görülmemiştir. Aksine, Anayasa tasarısın[da]... yer alan '18 yaşını dolduran ve kısıtlı veya kamu hizmetinden yasaklı olmıyan her Türk, Millet Meclisi seçimlerinde seçmendir.' şeklindeki hükmünün metinden çıkarılmış bulunması seçmenlik için Anayasa’nın yaş tâyin etmek istemediğini ve bunu Özel kanuna bıraktığını gösterir. Nitekim ... (Vatandaşlar, kanunda gösterilen şartlara uygun olarak, seçme ve seçilme hakkına sahiptir) denilmiştir. Buna göre seçmenlik yaşının belirtilmesi bir Anayasa meselesi değildir. / ... Anayasa'nın 55 inci maddesindeki seçme hakkını, 298 sayıl kanunun 6 ncı maddesinin yaş bakımından sınırlaması, bu hakkın özüne dokunmamaktadır". AYM, E. 1963/192, K. 1963/161, K.T. 21.06.1963.

97 "Anayasaya göre seçmen yaşının kanunla düzenlenmesi gereklidir. Yasa Koyucunun bu konudaki takdir yetkisini bu ölçüde kullanmış olmasında Anayasa'nın demokratik hukuk devleti ilkesi ile bağdaşmayan veya seçme hakkının özüne dokunan bir yön yoktur. ... / ... itiraz konusu kural, yirmibir yaşını dolduran herkesi kapsadığı, herhangi bir kişiye veya zümreye bir imtiyaz tanıyan nitelik taşımadığı için Anayasa'nın 12. maddesine ... aykırı olmadı̆̆ı...”. AYM, E. 1975/147, K. 1975/201, K.T. 21.10.1975.

98 "Şayet Anayasa Koyucu, seçmen yaşının erginlik yaşı olmasını isteseydi, Anayasanın 68., 72. ve 95. maddelerinde yaptı̆̆ gibi bunu da açıkça belli ederdi, yukarıda değinildiği gibi, belli etmek bir yana bunun tamamen tersini yapmıştır. / ... yasa koyucu kamu yönetimiyle ilgili hakların kullanılmasında, bunların etki ve önem derecelerine göre farklı yaşlarda olma ilkesini benimsemiştir. / 298 Sayıl Kanunun 6. maddesi de seçmen olarak kamu yönetimine katılabilmek için, medenî hukuk alanındaki işlerde aranan ehliyet yaşından farklı olan bir yaşın, yani 21 yaşın doldurulmasın uygun bulmuştur. Yasa Koyucunun bu takdirinde Anayasa ilkelerine ters düşen bir yön yoktur. Ancak ... Yasa Koyucunun, günün ekonomik ve sosyal koşullarının gerektirmesi halinde yeni bir kanunla seçmen yaşını 18'e indirmesine Anayasa açısından bir engel de bulunmamaktadır". AYM, E. 1977/123, K. 1978/16, K.T. 16.02.1978. Kararda, önceki kararlara da referans yapilır. Bkz. K. 1963/161, K. 1975/201.

99 Karşı oy (Hasan Gürsel): "Medenî Kanunumuza göre 18 yaşını bitiren ... kişi serbestçe evlenip aile yuvası, ticari şirketler ve dernekler kurabilir, her türlü hukukî bağlantılarda bulunabilir, bir suç işlerse ceza kanunlarına göre tam ceza sorumluluğu altındadır. 18 yaşını bitiren vatandaş siyasî parti üyesi olabilir, siyasî partilerde her çeşit faal görevler alabilir, parti başkanı dahi seçilebilir. / Yukarıda bir kısmı sıralanan medenî ve siyasî hakların kullanıcısı olan 18 yaşındaki bir vatandaşın seçim hakkını kullanabilmesi için ... 21 yaşını beklemesi, normal ve haklı bir teşrî̀ düzenleme değildir”. K. 1975/201. 


\section{1995: Kadına ilk kez I 8 yaşında oy kullanma hakkı}

Anayasa değişikliği ile, seçmen yaşı 20'den 18’e indirildi. Tercih, doktrinde Avrupa'daki düzenlemelerle de uyumlu bulundu ${ }^{100}$.

Anayasaya uyum sağlamak için, ayrıca kanun da değiştirildi. Ne var ki, seçimde oy kullanmanın diğer şartları düzenlenmemişti. Anayasa'da 18 yaşını doldurana seçme hakkı tanınmasına karşın, kanunun bu hakkı kullanmayı kolaylaştıracak hiçbir düzenlemeye yer vermediği, dolayısıyla yeterli güvence sağlamadığı gerekçesiyle iptali istendi. Bu bağlamda, demokratik hukuk devleti, millî egemenlik ilkesi ve seçme hakkına aykırılık olduğu ve hakkın engellendiği iddia edildi ${ }^{101}$. AYM ise, 2 karşı oya rağmen iddiayı reddetti ${ }^{102}$.

Böylece tarihimizde 2. kez, kadın-erkek siyasî rüşt yaşı ile medenî rüşt yaşı eşitlenmiş oldu. Ancak kadın ve erkek açısından bakınca, bu bir ilktir ${ }^{103}$. Zira 1923'teki eşitleme sadece erkekler açısından geçerli idi.

Değişiklik genel olarak olumlu bulunmuş olup ${ }^{104}$, biz de eşitleme tercihinin gerek oy hakkının genelliği ilkesine, gerekse demokratik ilkelere uygun olduğu kanaatindeyiz.

2003 Anayasa değişiklikleri sırasında bu kez seçilme yaşının eşitlenmesi gündeme gelse de polemiğe konu olmaktan öteye geçmedi ${ }^{105}$.

100 İbrahim Özden Kaboğlu, Anayasa Hukuku Dersleri (Genel Esaslar) (16. Bası Legal 2021) 211.

101 "[B]ir hakkın kullanılabilmesi için Anayasa'da tanınmış olması yetmez, ayrıca bu hakkın kullanımının yasa ile de düzenlenmesi gerekir. / Ancak, ... 18 yaşını bitiren seçmenlerin yazımı, yine aynı Yasa'da düzenlenen 'sandık seçmen listelerine itiraz' biçimiyle yapılacaktır. / ... ilk kez yazılması gereken yurttaş sayısı 8.000 .000 (Sekiz milyon) dolayındadır ki, bu 10 günlük süre içinde her gün 800.000 (sekizyüzbin) kişinin ... yazllmasını gerektirir. / ... Bu durumda, seçmen sıfatını Anayasa değişiklikleriyle ilk defa kazanmış olanların kendilerini yazdırmaları, yeni bir takım formaliteleri yerine getirmeleri gerekecektir. Oysa, aslolan seçmenlerin seçmen kütüğüne kamu makamlarınca yazılmasıdır. Yasa, daha önce yazılmış seçmenlere göre yeni seçmenlere yüklediği bu 'külfet'le seçme hakkının kullanımını güçleştirmektedir. Seçmenin kendisini yazdırması ancak, itiraz gibi arizi durumlar için sözkonusudur. Bir anayasal hakkın kullanılması, ancak itiraz durumlarında kullanılması gereken bir yönteme bağlanamaz". AYM, E. 1995/54, K. 1995/59, K.T. 18.11.1995, başvuru gerekçesi.

102 “... oyverme hakkını engelleyen bir durum söz konusu değildir. Yazım başlangıcıyla oy verme günü arasındaki sürenin kısalığı Yasa’nın Anayasa’ya aykırılığını değil uygulama güçlüklerini gündeme getirir. Kaldıki Yüksek Seçim Kurulu’nca yazım için belirlenen on günlük süre de bu sorunu çözmeye yeterlidir”. K. 1995/59.

103 “Böylece, anayasa hukukumuzda ilk defa kadın-erkek normal rüşt yaşı ile siyasî rüsst yaşı eşitlenmiştir”. Bülent Tanör \& Necmi Yüzbaşığlu, 1982 Anayasasına Göre Türk Anayasa Hukuku (9. Bas1 YKY 2009) 207.

104 Ekici (n 54) 63; Bahadır Koç, 1982 Anayasası'na Göre Siyasal Haklar ve Ödevler (Yüksek Lisans Tezi Selçuk Üniversitesi Sosyal Bilimler Enstitüsü 2011) 58.

105 Resul Tosun (Ak Parti): “Seçme yaşı 18, seçilme yaşı 30; aslında, ortada bir çelişki var. ... Biz, Türkiye’yi yönetecek insanları seçebilmek için 18 yaşın yeterli görürken, ... eğer meseleye sadece yaş açısından bakarsak, bir çelişki içinde olduğumuzu görürüz”. Orhan Eraslan (CHP): "Zekâ yaşına da bakmak lazım!” TBMM Tutanak Dergisi, Dönem: 22, Yasama yılı: 1, Birleşim 59, 01.04.2003-Salı 63. 


\section{20 I 7: Seçme ve seçilme yaşında eşitleme}

Seçilme yaşı, ilk kez 18’e indirildi. Böylece öncekinden farklı olarak (medenî ve siyasî rüş̧ yaşında eşitleme), bu kez ilk defa seçme ve seçilme yaşı eşitlenmiş oldu.

Dolayısıyla, oy kullanma yaşı, - 1934 hariç - gerek Türkiye Büyük Millet Meclisi (TBMM) ve gerekse yerel seçimlerde sürekli düşme eğiliminde oldu.

Tablo I: Seçme Yaşında Gelişim (TBMM)

\begin{tabular}{|c|c|c|c|}
\hline Tarih & Düzenlenen norm & Cinsiyet & Yaş \\
\hline 1876 & Talimât & $\mathrm{E}$ & 25 \\
\hline 1921 & - & $\mathrm{E}$ & - (düzenlenmez) \\
\hline 1923 & Kanun değ. & $\mathrm{E}$ & 18'i ikmâl \\
\hline 1924 & Anayasa & $\mathrm{E}$ & $18^{\prime}$ 'i ikmâl \\
\hline 1934 & Anayasa değ. & $\mathrm{E}+\mathrm{K}$ & 22 'yi ikmâl \\
\hline 1961 & Kanun & $\mathrm{E}+\mathrm{K}$ & $21^{\prime} \mathrm{i}$ doldurma \\
\hline 1982 & Anayasa & $\mathrm{E}+\mathrm{K}$ & 21'i doldurma \\
\hline 1987 & Anayasa değ. & $\mathrm{E}+\mathrm{K}$ & 20'ye girme \\
\hline 1995 & Anayasa değ. & $\mathrm{E}+\mathrm{K}$ & 18'i doldurma \\
\hline
\end{tabular}

Gelişimi bir çizgi grafik üzerinde somutlaştırma, başlıca kırılmaları yansıtacaktır. Aşağıda açıkça görüldüğü üzere, yaş eğrisinin düşme eğilimindeki tek istisna, 1934’te gerçekleşmiştir.

Grafik I: Seçme Yaşında Gelişim (TBMM)

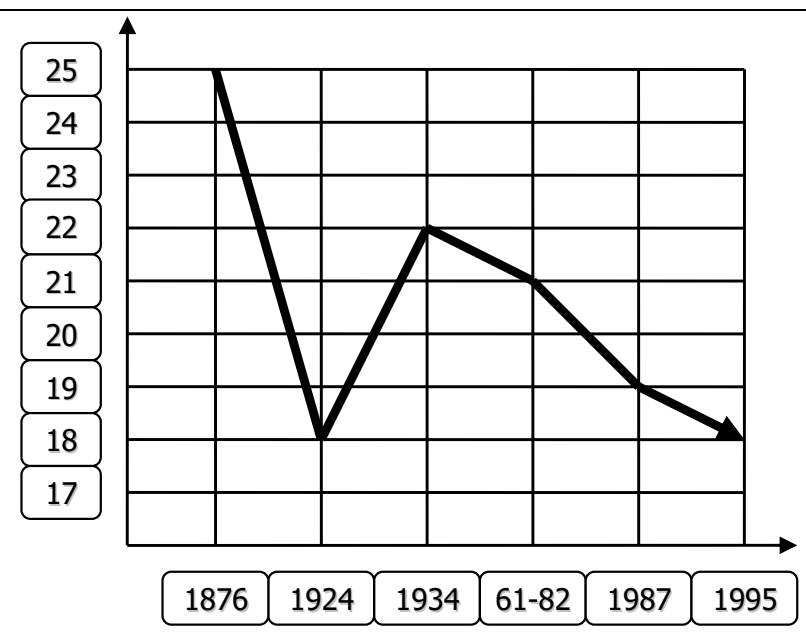




\section{B. "I 8 YAŞI DOLDURMA” ŞARTI VE ANLAMI}

\section{Anayasa ve kanun'daki düzenleme}

Seçmen yaşı "en üst norm" olan Anayasa'da belirlenmekte olup, aynı yaş ilgili Kanun'da da tekrarlanır (Normlar arasındaki tek fark aşağıda altı çizilen sözcükler olup, önemsiz sayılabilir):

- 1982 Anayasası, m. 67/3: "Onsekiz yaşını dolduran her Türk vatandaşı seçme ve halkoylamasına katılma haklarina sahiptir”.

- STHK, m. 6: "Onsekiz yaşııı dolduran her Türk vatandaşı seçme ve halk oylamasına katılma hakkina sahiptir".

Seçme ve seçilme yaşının Anayasảda gösterilmesi hiç kuşkusuz önemli bir güvencedir. Zira, kanunla bu sınırın altında bir yaş belirlenmesi dahi mümkün iken, aşılması olanaksız hâle gelmiş olur. Ayrıca, özellikle - Türkiye gibi - katı anayasa sisteminin tercih edildiği örneklerde bu yaşı yükseltmek, türev kurucu iktidar sıfatıyla (anayasa normunu değiştirme veya ilga yoluyla) daha zor olduğu hâlde, kurulu iktidar sıfatıyla (kanunu yapma, değiştirme veya ilga yoluyla) nispeten daha kolay ve güvencesizdir.

Hâl böyle iken, anayasal düzeyde düzenleme, istisnanın kanunla düzenlenmesine de kesin bir engel teşkil eder. Diğer deyişle, eğer makûl gerekçeye dayanan bir istisna getirilecekse, bu da aynı düzeyde normda (Anayasa) yer almalıdır. Aksi hâlde AYM'nin iptal yaptırımı devreye girecektir.

Nitekim Anayasa m. 67/l'e göre, vatandaşlar seçme hakkını "kanunda gösterilen şartlara uygun olarak" kullanabilirler. Ancak Anayasayı kaleme alan irade, kanuna yaptığı bu referansa karşın, yaş şartını doğrudan Anayasa ile düzenlemiştir:

"Onsekiz yaşın dolduran her Türk vatandaşı seçme ve halkoylamasına katılma haklarına sahiptir" (m. 67/3).

Anayasa m. 67'de yaş şartı 18'i doldurma olarak belirlenmesine karşın, f. 4'te kanuna tekrar referans yapılırken, sınırlama değil, "düzenleme" izni verilir. Dolayısıyla, bahse konu f. itibariyle seçme hakkının, yaş boyutu açısından nitelikli veya basit yasa kaydı değil, "yasa kayıtsız" kategoriye dâhil olduğu kanısındayız:

"Bu hakların kullanılması kanunla düzenlenir" (m. 67/4).

Buna göre, söz konusu yaşın yasayla yalnızca tekrarlanması veya anayasal ilkelere uygun olmak kaydıyla "doldurma"nın anlamının açıklığa kavuşturulup somutlaştırılabilmesi mümkündür. Nitekim, buna karşın, yasayla yaşın yükseltilmesi veya istisnasının oluşturulması yolu ise kapatılmıştır. Nitekim ilgili Kanun m. 6, "doldurma"nın anlamını açıkça belirlediği için, hakkın kullanımını yaş boyutu itibariyle kişi bakımından daraltma (sınırlama) değil, 18 yaşı doldurmanın anlamını açıklığa kavuşturduğu için bir somutlaştırma (düzenleme) maddesidir. 


\section{2. “I 8 yaşı doldurma" şartında yıl ve gün}

Esasen yaş olgusu yılla ilgili bir konu olmasına karşın, gerek "yaşı doldurma” şartı ve gerekse seçimin zamana bağlı kullanılan bir hak/özgürlük olması dolayısıyla "seçim günü” kaydı, doğum gününü de önemli hâle getirmektedir. Seçmen yaşı en üst norm düzeyinde Anayasa'da belirlense de, 18 yaşı doldurma şartının ne zaman gerçekleşmiş sayılacağı hususu düzenlenmemekte ve kanuna bırakılmaktadır. Bu yüzden, yaşa ilişkin diğer kurallar Kanun'da düzenlenmektedir. Bu bağlamda, aşağıdaki norm, anayasa normunun (Anayasa m. 67/3) bir anlamda tekrarından ibârettir.

"Onsekiz yaşını dolduran her Türk vatandaşı seçme ve halk oylamasına katılma hakkına sahiptir" (STHK m. 6).

Oysa Kanun'daki diğer ilgili norm, yaşı tekrar etmek yerine, söz konusu Anayasa normunda geçen "onsekiz yaşını doldur"ma şartını somutlaştırmakta ve açıklığa kavuşturmaktadır. Diğer deyişle aşağıdaki norm, Anayasa’nın sonraki fıkrasındaki (m. 67/4) "kanunla düzenlenir” kuralının gereği olan bir "düzenleme" normudur:

"Bu Kanunun uygulanmasında herkes, nüfus kütüğ̈̈nde yazılı bulunan doğduğu ay ve güne göre işleme tabi tutulur. Ancak, o yıl seçim yapılması durumunda seçmen listeleri hazırlanırken on sekiz yaşın doldurulmuş olmasının hesabında seçim günü (o gün dahil) esas alını" (STHK m. 34/3 ${ }^{106}$ ).

Anayasa ve yasa hükümlerinden, 18 yaşın hesaplanmasına ilişkin bazı ilkesel çıkarımlar yapılabilir ${ }^{107}$ :

• İlke 1: Yaş, “yazım günü” itibarıyla değil, “seçim günü” itibarıyla hesaplanır.

- İlke 2: Yaş, yıl olarak değil, “ay ve gün” olarak hesaplanır.

- IIlke 3: Hesaplamada yaşa girmiş veya işlemekte olmak yetmez, "doldurmuş olma” şartı aranır.

Özetle, kişi doğduğu gün itibariyle 18 yaşını doldurduğu güne rastlayan seçimde ve sonrasındaki her seçimde, gün içindeki doğduğu saate bakılmaksızın ${ }^{108}$ oy kullanabilecektir.

106 Şu anda (10 Aralık 2021 tarihi itibariyle) yürürlükte olan ve yukarıda aktardığımız metin, 1995’te yapılan değişiklikle kabûl edilmiştir. Kanun no. 4125, kabûl tarihi: 27.10.1995. Kanun’un ilk metni epeyce eskiye dayanır. Kanun no. 298, kabûl tarihi: 26.04.1961. 1979'da getirilen değişiklik ise, oldukça farklıdır: "298 sayıl Kanunun uygulanmasında, herkes, nüfus kütüğ̈̈nde doğduğu ay ve günün yazılmış olup olmadığına bakılmakszzın, nüfus kütü̈̆̈̈unde gösterilen doğum yılının son günü doğmuş gibi işleme tabi tutulur" (m. 34/3). Kanun no. 2234, kabûl tarihi: 17.05.1979. 21 yaşın geçerli olduğu dönemde benzer hüküm, halkoylaması için geçici hükümle de getirilmiştir (ek geçici m. 1/4): "Kütüklerde ismi bulunmayanlardan, seçmen kütüklerinin kesinleştiği tarihe kadar 21 yaşım bitirmiş olanlar, başvuruları üzerine seçmen kütüklerine kaydedilirler. Nüfus kütüğ̈̈nde doğduğu ay ve günü belli olmayanlar o ylln son günü doğmuş gibi işleme tabi tutulurlar". Kanun no. 2812, kabûl tarihi: 05.04.1983.

107 Gözler (n 18) 484.

108 Buna göre, seçim gününe tekabül eden 18 yıl önceki aynı günün akşam saatinde sandıklar kapandıktan sonraki bir saatte doğan kişi, gün içinde hangi saatte oy kullanırsa kullansın, aslında 18 yaşını fiilen tam olarak doldurmasa da, hukuken doldurmuş kabûl edilip hak sahibi kılınmaktadır. Benzer durum, sandıkların kapatılmasından önceki bir saatte doğduğu hâlde, sabah erken saatte oyunu kullanan seçmen için de geçerlidir. Ancak bu tercih, zorunluluktan kaynaklanmakta olup, isabetli ve makûldür. 
Ancak bu durum, doğum günü belirli olan kişiler için geçerlidir. Bir diğer husus ise, doğum gününün yıl olarak belirli olmasına karşın, gün olarak belirsiz olmasıdır. 1960'larda yayınlanan bir seçim kanunu şerhinde aktarıldığına göre, Dahiliye Vekâleti’nin 24.02.1954 T. ve 56 no.lu yazısına cevaben Adliye Vekâleti mütalâası ile verilen görüşe göre, bu tür durumlarda bulunan şahısların lehine yorumla, yılın ilk gününde doğduklarının kabûl edildiği görülür ${ }^{109}$. Önceki kuşağın nüfus cüzdanlarında "01.01.1954" gibi sonradan eklenen doğum tarihleri görülse de, günümüzde artık doğumlar günü gününe, hatta saat ve dakika itibariyle kayıt altına alındığı için, benzer sorunların oldukça azaldığı belirtilebilir.

\section{SONUÇLAR VE ÖNERILER}

Tüm tartışmalardan ulaştığımız sonuçların yanı sıra, inceleme konumuzla doğrudan ve dolaylı ilgili olduğunu düşündüğümüz iki öneriyi özetleyeceğiz.

\section{A. SONUÇLAR}

Çalışmamızda, seçme hakkında yaş şartının makûl bir sınır olduğu, ancak belirlenen yaşın konu (seçim türü), yer, zaman, kişi vb. açılardan ayrımcı uygulanmasının reddedilmesi gerektiği belirtildi.

Hatta bu bağlamda, birtakım ideal ilkeler denemesi yapıldı: Medenî ve siyasî rüşt yaşında eşitlik, seçim türüne göre yaş şartında eşitlik, oy hakkı ve seçme hakkı açısından eşitlik, oy hakkı ve diğer siyasal faaliyetler açısından eşitlik, seçme ve seçilme hakkı açısından eşitlik, yaş şartını kişi açısından ayrımcı uygulamama, yaşı düşürme ve artırmama, vb.

İlkelerden ilk 5’i yaş şartını saptamada eşitlik, 6. ilke uygulamada eşitlik, sonuncusu ise hakta geri götürmeme ilkesidir (geliştirme görevi).

Söz konusu ilkeler açısından bakınca; - 18 yaşı doldurma koşulunun pratiğindeki sorunları rezerv tutmak kaydıyla ${ }^{110}$ - 2017 Anayasa değişikliği ile seçme ve seçilmede yaşın eşitlenmesiyle, 1982 Anayasası’nın belirlediğimiz ideal ölçütlerle uyumlu hâle geldiği sonucuna varabiliriz.

109 "Ceza hukukunda kabul edilmiş bulunan umumî prensibe kıyasen, 1932 senesinde doğup da nüfusta ayı günü belli olmıyan şahısların lehine hareket edilerek bunların 932 senesinin ilk gününde yani 1/1/1932 tarihinde doğmuş olduklarının kabulü. / 954 Milletvekilleri seçiminin 2/5/1954 tarihinde yapılması düşünülmekte olmasına göre, 932 senesinde doğup da nüfusta ayı günü belli olan şahısların 2/5/1932 günü saat 0 ile rey atımının başlangıç saati olan 8 arasında doğmalarının mümkün bulunduğu nazara alınp yine lehte hareket edilerek, en son 2/5/1932 tarihinde doğmuş olanlarla bunlardan büyük bulunanların Milletvekilliği seçmen kütüklerine kaydı, / muvafık görülmektedir”. Akt. Erdoğan (n 43) 31.

110 Ancak, 18 yaşın uygulanmasında bazı sorunlar olduğu da gerçektir. 2019 İstanbul Büyükşehir Belediye Başkanlığ 1 seçiminin “tekrar"ında tanık olunduğu üzere, 18 yaşı "doldurma” şartını iki seçim arasında kazanan seçmenlere 2. seçimde oy kullandırılmaması, hak temelli yorumla çelişen bir uygulama olmanın ötesinde, Anayasa ve yasaya da açıkça aykırıdır. Zira, yaş boyutu itibariyle "yasa kayıtsız hak" niteliğine sahip olan seçme hakkının bu açıdan sınırı doğrudan Anayasa'da belirlendiği ve yasayla aşılamayacağı, üstelik yasada da açıkça sınırlanmadığı için, söz konusu uygulama yanlıştır. Ancak bu konu başkaca bir çalışmanın konusu olduğu için, şimdilik yalnızca sorunu saptamakla yetineceğiz... 


\section{B. ÖNERILER}

İlkin, kademeli sınırlama tezi, hak ve özgürlüklerin farklılaşmış kategorilere dâhil olması esasına dayanır: Basit yasa kaydı, nitelikli yasa kaydı, yasa kayıtsız hak, mutlak hak. Bir hak veya özgürlük, farklı boyutlarından (kişi, konu, zaman, mekân, vb.) biri itibariyle bir kategoride, bir başka boyutu itibariyle başka kategoride yer alabilir. Dolayısıyla, hak veya özgürlüğün tüm boyutlarını kapsayacak biçimde genel bir nitelemenin isabetsiz yorumlara yol açabileceğini düşünüyoruz. Bu sebeple, haklarda her boyut açısından ayrı değerlendirmeler yapılarak, her birine uygun düşen sınırlama rejiminin belirlenmesini öneriyoruz. Bu açıdan bakınca, Anayasa m. 67'de seçme hakkına "kanunda gösterilen şartlara uygun olarak” sahip olunması ilkesi (f .1), - sayılan diğer haklar (seçilme, siyasi parti içinde siyasi faaliyette bulunma, halkoylamasına katılma) üzerine tartışmayı bir yana bırakarak - konumuz olan seçme hakkı (ve özellikle yaş boyutu açısından) açık bir sınırlama formülü içermemektedir. Ancak, velev ki f. 1'deki ibâre "basit yasa kaydı" olarak nitelense dahi, Anayasa m. 13’teki güvence ölçütlerinin getirdiği korumanın devam edeceğini kabûl etmek gerekir ${ }^{111}$. İzleyen fikrada ise, kanunun "uygulanabilir tedbirleri" yurt dışındaki vatandaşların "oy hakkını kullanabilmeleri amacı" ile belirleyeceği (f. 2) belirtilmektedir. "Bu hakların kullanılması kanunla düzenlenir" hükmünü içeren $\mathrm{f}$. 4 ise, 18 yaş şartını belirleyen $\mathrm{f}$. 3 'ten sonra geldiği için, seçme hakkının yaş boyutu itibariyle kişi bakımından "yasa kayıtsız" kategoriye dâhil olduğu sonucuna varıyoruz. Üstelik, f. 1'in düzenleme değil sınırlama hükmü olarak değerlendirilmesi hâlinde dahi, yaş şartı f. 3’te açıkça düzenlendiğinden, f. 1 için yapılabilecek herhangi bir "basit yasa kaydı" nitelemesinin f. 3’ü kapsamayacağı görüşündeyiz. Ayrıca, seçme hakkı kişi bakımından doğrudan anayasa ile 2 açıdan (yaş ve vatandaşlık) daraltılmış olmanın ötesinde, hak sahibinin (seçmen) istediği zaman, istediği yerde ve istediği konuda oy kullanması (zaman, mekân, konu) hakkın doğası gereği kendine özgü sınırlarla çevrilidir. Bu bağlamda, seçme hakkının sahibi söz konusu iki açıdan kanuna bırakılmayıp doğrudan Anayasa ile belirlendikten sonra, belirli usûlî koşullara bağlayan diğer normların amacı ise, hak-hak (seçme hakkı-seçilme hakkı) ya da hak-anayasal değer (seçme hakk1-seçimin dürüstlüğü) arasında âdil bir denge kurmaktan ibârettir. Nihayet, "seçim kanunlarının temsilde adalet ve yönetimde istikrar ilkelerini bağdaştıracak biçimde düzenlen"mesini emredici Anayasa normu ise (f. 6), bu kez iki anayasal değer arasında âdil denge kurulmasını temine yöneliktir.

İkinci olarak, bu vesileyle bir başka hususun daha altını çizmekte yarar görüyoruz: 2001'de Anayasa değişikliği ile 9 genel sınırlama nedeninin Anayasa m. 13’ten çıkarılması sonrasında nitelikli yasa kaydı içeren maddelerde sınırlama olanağı azalmasına karşın, aynı çıkarımı basit yasa kayıtlı maddeler için yapmak güçtür. Zira, daha önce 9 nedenle sınırlı bir listeyi kullanabilen yasa koyucunun, 2001 sonrasında ucu açık listeden neden seçebilmesinin yolunun açıldığı kabûl edilirse, basit yasa kayıtlı hakların öncesine oranla daha zayıf biçimde korunuyor olduğu sonucuna ulaşmak gerekecektir. Ne var ki, ulaşılan bu sonuç, 2001 Anayasa değişikliğinin temel amacı ile açık biçimde

111 Zira basit yasa kaydına tâbi bir hak, meşrû neden bakımından daha geniş sınırlamaya maruz kalsa ve yasa koyucunun takdir alanı genişlese de, m. 13’teki güvence ölçütleri (hakkın özü, ölçülülük, vb.) devre dışı kalmayıp, ayrıca hakkın düzenlendiği maddedeki esaslara uygunluk gereği de devam etmektedir. Sibel İnceoğlu, 'Hak ve Özgürlükleri Sınırlama ve Güvence Rejimi’ İnsan Hakları Avrupa Sözleşmesi ve Anayasa Ed. Sibel İnceoğlu (Avrupa Konseyi 2013 ) 24. 
çelişecektir. Dolayısıyla, sınırsız liste yerine, Anayasa'daki nedenlerle sınırlı bir analizin yapılması gerektiği kanısındayız.

Bu çerçevede, özetlediğimiz her iki önerinin tartışılması, yalnızca seçme hakkı değil, tüm hakların yorumlanması açısından katkı sağlayabilir.

\section{KAYNAKÇA}

90 Yılda 90 Belge (TBMM Genel Evrak ve Arşiv Müdürlüğü 2010).

AB Üyesi Bazı Ülkelerin Anayasaları (Adalet Bakanlı̆̆ı 2011).

Akbulut O, 'Serbest Seçim Hakkı' İnsan Hakları Avrupa Sözleşmesi ve Anayasa Ed. Sibel İnceoğlu (Avrupa Konseyi 2013) 543-555.

Akdağ N, Türkiye Tarihinde İlk’ler (Yeşil Elma 2009).

Aliefendioğlu Y, ‘Temsili Demokrasinin 'Seçim’ Ayağı' (2005) 60 Türkiye Barolar Birliği Dergisi 71-96.

Anayurt Ö, Anayasa Hukuku: Genel Kısım (3. Bası Seçkin 2020).

Armağan S, 'Türkiye'de Parlamento Seçimleri' (1967) 33/3-4 İstanbul Üniversitesi Hukuk Fakültesi Mecmuası 45-100.

Atatürk, Medeni Bilgiler: Türk Milletinin El Kitabı Haz. Ayşe Afet İnan (2. Bası Toplumsal Dönüşüm 2010).

Atatürk, Teşkilât-ı Esasiye Kanunu (Proje Hâlindedir) 1339-1342 (Boyut 1998).

Atatürk, Teşkilât-ı Esasiye Kanunu: Ek Kitapçı: Temel Kuruluş Yasası: Türkiye Cumhuriyeti İlk Anayasa Taslağı: Türkçeleştirilmiş Metin (Taslak halindedir) (Boyut 1998).

Brown B, 'If You're Old Enough to Fight, You're Old Enough to Vote' Public Land \& Resources Law Review (2020) 43/30 August 60-85. https://scholarship.law.umt.edu/plrlr/vol43/iss1/30 (erişim tarihi: 11.03.2021).

Çavdar T, Türkiye’nin Demokrasi Tarihi (İmge 1995).

Devellioğlu F, Osmanlıca-Türkçe Ansiklopedik Lûgat (Eski ve Yeni Harflerle) (16. Bası Aydın 1999).

Doğru O \& Nalbant A, İnsan Hakları Avrupa Sözleşmesi: Açıklama ve Önemli Kararlar C. 2 (Avrupa Konseyi 2013).

Döner A, Türk Anayasa Hukuku (Yetkin 2021).

Ekici S, 1982 Anayasasında Seçme ve Seçilme Hakları (Yüksek Lisans Tezi Ankara Üniversitesi Sosyal Bilimler Enstitüsü 2009).

Erdem T, Anayasalar ve Seçim Kanunları (1876-1982) (Milliyet 1992)

Erdoğan F, Türk Seçim Mevzuatı ve Tatbikatı (Ege 1960).

Eren A, Anayasa Hukuku Dersleri (3. Bası Seçkin 2021)

Eroğul C, Anatüzeye Giriş (15. Bası İmaj 2016).

Eroğul C, Devlet Yönetimine Katılma Hakkı (İmge 1991).

Gözler K, Türk Anayasa Hukuku (2. Bası Ekin 2018).

Gözübüyük A Ş \& Sezgin Z, 1924 Anayasası Hakkında Meclis Görüşmeleri (Ankara Üniversitesi Siyasal Bilgiler Fakültesi 1957).

Hanski R \& Scheinin M, İnsan Hakları Komitesinin Emsal Kararları Çev. Defne Orhun (İstanbul Bilgi Üniversitesi 2005).

Harris D J \& Q’Boyle M \& Bates Ed P \& Warbrick C, Avrupa İnsan Hakları Sözleşmesi Hukuku Çev. Mehveş Bingöllü Kılıcı \& Ulaş Karan (Avrupa Konseyi 2009).

İnan A, Atatürk Hakkında Hatıralar ve Belgeler yay. haz. Arı İnan (8. Bası Türkiye İş Bankası 2009). 
İnceoğlu S, 'Hak ve Özgürlükleri Sınırlama ve Güvence Rejimi’ İnsan Hakları Avrupa Sözleşmesi ve Anayasa Ed. Sibel İnceoğlu (Avrupa Konseyi 2013) 23-52.

Johnston N \& Uberoi E, 'Voting Age' (2020) 1747 House of Commons Library Briefing Paper 19 November 2020 5.

Kaboğlu İ Ö, Anayasa Hukuku Dersleri (Genel Esaslar) (16. Bası Legal 2021).

Karamustafaoğlu T, Seçme Hakkının Demokratik İlkeleri (Ankara Üniversitesi Hukuk Fakültesi 1970).

Karatepe Ş, Anayasa Hukuku (Savaş 2013).

Karpat K, Türk Demokrasi Tarihi (Timaş 2010)

Koç B, 1982 Anayasası'na Göre Siyasal Haklar ve Ödevler (Yüksek Lisans Tezi Selçuk Üniversitesi Sosyal Bilimler Enstitüsü 2011).

Milletvekili Genel Seçimleri: 1923-2011 (Türkiye İstatistik Kurumu 2012).

Mumcu A, '1924 Anayasası' (1986) 2/5 Mart Atatürk Araştırma Merkezi Dergisi 383-399.

Mumcuoğlu M, Çağdaş Demokrasi Kuramlarında Katılma ve Türkiye’de Katılmanın Gelişimi (Doçentlik tezi Ankara Üniversitesi Hukuk Fakültesi 1982)

Nohutçu A. \& Ziyrek A, Osmanlı Türk Anayasa Metinleri (Savaş 2020).

Olgun K, 'Türkiye’de Cumhuriyetin İlanından 1950’ye Genel Seçim Uygulamaları' (2011) 27/79 Atatürk Araştırma Merkezi Dergisi 1-35.

Ormanoğlu H D, Demokratik Sistemlerde Temsilde Adalet ilkesinin Gerçekleştirilmesi (Doktora Tezi Hacettepe Üniversitesi Sosyal Bilimler Enstitüsü 2019).

Özbudun E, 1924 Anayasası (Bilgi Üniversitesi (2012).

Özdemir S S, Kadın Hakları Bağlamında Türkiye’de Pozitif Ayrımcılık İlkesi (XII Levha 2019).

Özön M N, Küçük Osmanlıca-Türkçe Sözlük (4. Bası İnkılâp 1998).

Sağlam F, Anayasa Hukuku Ders Notları (Yakın Doğu Üniversitesi Hukuk Fakültesi 2013).

Savcı B, 'Seçmenlik Şartları Bakımından Seçim Rejimi’ (1947) 2/3 Ankara Üniversitesi Siyasal Bilgiler Fakültesi Dergisi 217-234.

Seleman C, 'Around the World: Children's Suffrage: Giving 16 Year Olds the Right to Vote' (2018) 38/2 Article 8 Children's Legal Rights Journal 174-177. https://lawecommons.luc.edu/clrj/vol38/iss2/8 (erişim tarihi: 11.03.2020).

Sezer A, 1982 Anayasası Ekseninde Türev Kurucu İktidar Yetkisinin Sınırları ve Yargısal Denetimi (Doktora tezi Marmara Üniversitesi Sosyal Bilimler Enstitüsü 2006).

Sezer A, Demokrasi Teorisi ve Pratiğinde Seçim Barajları [Adalet-İstikrar İkileminde \% 10 Ulusal Baraj Açısından Karşılaştırmalı Bir Analiz] (Legal 2014).

Sezer A, Ulusal-üstü Belgeler ve Önceki Anayasalarla Karşılaştırmalı \& Gerekçeli \& Açıklamalı 1982 Türkiye Cumhuriyeti Anayasast ve İlgili Mevzuat (Beta 2004).

Şirin T, 'İnsan Hakları Avrupa Sözleşmesi’ne Göre Serbest Seçim Hakkı' (2011) 17/1-2 Marmara Üniversitesi Hukuk Fakültesi Hukuk Araştırmaları Dergisi 283-348.

Tanör B \& Yüzbaşığlu N, 1982 Anayasasına Göre Türk Anayasa Hukuku (2. Bası YKY 2009).

Tanör B, Osmanlı-Türk Anayasal Gelişmeleri (1789-1980) (4. Bası YKY 1999).

TBMM Albümü (1920-2010) C. I: 1920-1950 (2. Bası TBMM Basın ve Halkla İlişkiler Müdürlüğü TBMM 2010).

Teziç E, Anayasa Hukuku (Genel Esaslar) (21. Bası Beta 2017).

Uyar L, Birleşmiş Milletler'de İnsan Hakları Yorumları: Insan Hakları Komitesi ve Ekonomik, Sosyal ve Kültürel Haklar Komitesi 1981-2006 (İstanbul Bilgi Üniversitesi 2006).

Varlık Ü \& Ören B, Seçim Sistemleri ve Türkiye’de Seçimler (Der 2001). 
Yardımcı G, Avrupa İnsan Hakları Mahkemesi Kararlarıla Serbest Seçim Hakkı (Yüksek Lisans Tezi Ankara Üniversitesi Sosyal Bilimler Enstitüsü 2020).

Yılmaz F, Türk Anayasa Tarihi (1808-2010) (İz 2012).

\section{DIGGER KAYNAKLAR}

https://anayasa.gov.tr (AYM web sitesi).

https://www.cia.gov (CIA Factbook web sitesi).

https://www.constituteproject.org (Constitute Project web sitesi).

TBMM Zabıt Ceridesi, TBMM Tutanak Dergisi, Temsilciler Meclisi Tutanak Dergisi, vb.

'Voting age: What is the legal voting age in the national elections?', The Electoral Knowledge Network, https:// aceproject.org/electoral-advice/archive/questions/CDTable?question=ES004\&view=country\&set_ language $=e n$ (erişim tarihi: 11.03.2021).

\section{KARARLAR}

\section{A. AYM KARARLARI (NORM DENETIMI)}

AYM, E. 1963/192, K. 1963/161, K.T. 21.06.1963.

AYM, E. 1975/147, K. 1975/201, K.T. 21.10.1975.

AYM, E. 1977/123, K. 1978/16, K.T. 16.02.1978.

AYM, E. 1995/54, K. 1995/59, K.T. 18.11.1995.

AYM, E. 2018/69, K. 2018/47, K.T. 31.05.2018.

\section{B. IHAM KARARLARI}

Hirst v. United Kingdom (No. 2), Grand Chamber, App. no. 74025/01, Judg. 06.10.2005.

Mathieu-Mohin \& Clerfayt v. Belgium, App. No. 9267/81, Judg. 02.03.1987.

Ždanoka v. Latvia, Grand Chamber, App. No. 58278/00, Judg. 16.06.2006. 